\title{
Legumes for feed, food, biomaterials and bioenergy in Europe: a review
}

\author{
Anne-Sophie Voisin • Jacques Guéguen • Christian Huyghe • Marie-Hélène Jeuffroy • \\ Marie-Benoit Magrini • Jean-Marc Meynard • Christophe Mougel • Sylvain Pellerin • \\ Elise Pelzer
}

Accepted: 4 October 2013

(C) INRA and Springer-Verlag France 2013

\begin{abstract}
Legume growing has many benefits. Indeed legumes provide plant proteins for animal feed and human food. Legumes fix atmospheric $\mathrm{N}_{2}$ and, in turn, provide cheap and green $\mathrm{N}$ fertilisers. Additionally, legumes are used as diversification crops in rotations based on oilseed rape and cereals. Despite those benefits, legume crops in Europe represent less than $4 \%$ of arable lands, and European legume seeds are underused for animal and human nutrition. Nonetheless, European authorities are now fostering the development of legume crops for sustainable agriculture. Here, we analyse forage and grain legume-producing systems since 1950 in order to identify the actual constraints of legume development. We show that legumes can contribute to the agroecological transition for sustainable agriculture, food
\end{abstract}

\author{
A.-S. Voisin $(\square) \cdot$ C. Mougel \\ INRA, UMR1347 Agroécologie, BP 86510, F-21000 Dijon, France \\ e-mail: Anne-Sophie.Voisin@dijon.inra.fr \\ J. Guéguen \\ INRA, UR1268 Biopolymères Interactions Assemblages, \\ F-44300 Nantes, France \\ C. Huyghe \\ INRA, Centre Poitou-Charentes, BP 6, F-86600 Lusignan, France \\ M.-H. Jeuffroy $•$ E. Pelzer \\ INRA, UMR211 Agronomie, F-78850 Thiverval-Grignon, France \\ M.-B. Magrini \\ INRA, UMR 1248 AGIR, BP 52627, F-31320 Castanet-Tolosan, \\ France \\ J.-M. Meynard \\ INRA, UAR1218 Département SAD, BP1, \\ F-78850 Thiverval-Grignon, France \\ S. Pellerin \\ INRA, UMR 1220 TCEM, F-33883 Villenave d'Ornon, France
}

and energy and for sustainable agri-food systems. Then, we point out that high added-value niche markets are required for supporting legume production. The major research needs identified are (1) analysing the constraints of the current systems and identifying ways of moving towards systems that include more legumes, (2) identifying new and diversified uses for legumes in a sustainable food chain, (3) assessing and improving the ecosystem services provided by legumes at cropping system and territory scales and (4) promoting agroecology through and for legume crop management.

Keywords Legumes · Ecosystem services · Outlets · Agri-food system · Agroecology · Bioenergy · Biomaterials . Intercropping $\cdot$ France $\cdot$ Europe

Contents:

1. Introduction

2. Place of legumes in present and future farming and food systems

2.1. Reasons why legumes occupy a low position in the French farming systems of the 21st century

2.1.1 Fodder legumes: a decline linked to the intensification of agriculture

2.1.2 Grain legumes: a short-lived rise linked to developments in the Common Agricultural Policy

2.1.3. A deficit balance in protein-rich materials

2.1.4 A lock-in of sociotechnical systems

2.2. New issues in the development of legumes in the context of agroecological transition

2.2.1 From a demographic issue to a nutritional issue

2.2.2 Ecological challenges

2.2.3 Challenges for the territorialisation of resources

2.3. What instruments are there to encourage transition towards production systems integrating more legumes? 
2.3.1 The instruments for unlocking

2.3.2 What added value is there to support new niches encouraging legumes?

3. New research questions about legumes in the context of agroecological transition.

3.1. Analysing the lock-ins and identifying instruments of transition towards systems integrating more legumes

3.2. Identifying new and diversified outlets for legumes in a sustainable production chain

3.2.1 New outlets for food.

3.2.2 New outlets for the extraction of high added value compounds

3.2.3 New outlets for the production of bioenergy

3.3. Assessing the ecosystem services provided by legumes at production system and territory scales

3.3.1 Assessing the services at wider scales

3.3.2 Assessments with a view to improving the services provided by legumes.

3.4. Optimising the management of legume crops in a global approach to ecological intensification

3.4.1 Intercropping with several plant species

3.4.2 Interactions between plants and microorganisms of the rhizosphere

4. Conclusion: what transitions are there for researchers?

4.1. A new positioning of research questions

4.2. Collective implementation and learning about transition

4.3. What generic value is there in considering the example of France?

\section{Introduction}

The post-war agricultural revolution led to the intensification of European agriculture, between the 1950s and 1980s, with the development of mechanisation and increasingly intensive use of synthetic inputs. This intensification, and the structuring of the sectors that accompanied it, encouraged production systems to become highly specialised, with geographical separation of livestock from plant production and with increasingly short rotations. This evolution, based on the choice of species that could ensure the best short-term profitability, led to the abandonment of several species such as legumes which produced certain agronomic and environmental services (Schott et al. 2010). From the 1990s, growing uncertainty about the future availability of energy resources, increasing concern about the environment and the development of organic farming were the first signs that this capital-intensive and highly specialised agricultural production system was being called into question. Increasing recognition of the negative externalities associated with intensive systems (environmental pollution, greenhouse gas emissions, loss of biodiversity, etc.) encouraged some actors in the agricultural world to seek practices that were more environmentally friendly. But the transition towards more sustainable agriculture did not develop quickly, in spite of the recommendations advanced by many studies (Altieri et al. 1983; Hill and MacRae 1995; Millenium Ecosystem Assessment 2005; Aubertot et al. 2005; Le Roux et al. 2008; Butault et al. 2010). Such aims can be achieved by innovative production methods limiting the use of inputs and based on developing diversity and bio-(eco)-logical regulations in the agro-systems, collectively termed "agroecology" (Altieri 1992; Altieri and Nicholls 2012). But their development encounters a highly structured organisation of sectors and institutions, which leaves hardly any room for production systems breaking away from the present system (Vanloqueren and Baret 2009; Roep and Wiskerke 2012; Meynard et al. 2013). In addition, the increase of the world population, associated with a convergence of westernised incomes and lifestyles (including high consumption of meat products), calls into question whether agriculture will be capable of meeting the food requirements of the nine billion individuals who will be inhabiting the planet by 2050. A partial substitution for animal proteins by plant proteins could satisfy this increasing demand within the framework of the sustainable development of agricultural and food systems (Dorin et al. 2011).

In this context, legumes have several assets (Fig. 1): (a) at food system level, for human or animal consumption, legumes are a highly nutritious source of plant proteins that complement those of cereals; (b) at production system level, the capacity to fix air-borne nitrogen in symbiosis with soil bacteria makes them potentially highly suitable for inclusion in low-input, low greenhouse gas emission cropping systems; (c) in current cropping systems dominated by two or three major species, legumes play a role as diversification crops, breaking the cycles of pests and diseases, developing populations of beneficials for crop defence, reducing inputs for the other crops in the rotation, improving their use efficiency and increasing the quality of landscape mosaics. Consequently, legumes can play a major role in the agroecological transition towards more sustainable farming systems, with added positive effects expected in spheres related to agriculture (reduced energy consumption for manufacturing synthetic nitrate fertilisers, improving diets).

Paradoxically, in spite of their definite environmental interest and the important outlets that could exist not only for animal feed, but also for human consumption, legume land area is very low in European farming systems. However, various signals show that European authorities are willing to support the development of these crops. In view of this, the authors propose to give thought to deciding what research work would be the most appropriate to accompany this evolution. The situation of the French agriculture was chosen as a case study as it is representative of a wide range of 
Fig. 1 Pea crops in trials (centre), with their nodulated roots (left) and their seeds (right). Experiments in INRA Dijon, France
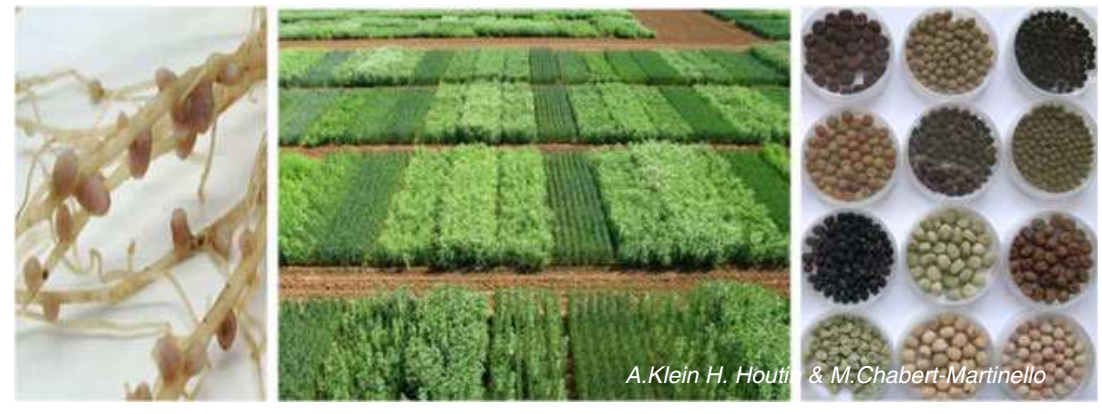

European agricultural systems. Using the example of France, the objectives of this article were thus (a) to highlight the reasons why such a small area of land is used for legumes and then to identify the instruments upstream and downstream of the sector which would help more legumes to be integrated into production systems, as a contribution to the agroecological transition of agriculture, then (b) in the light of this analysis, to propose a renewal of research questions in the various disciplines mobilised and finally (c) to learn lessons for the current organisation of research and for the need to encourage a stronger posture of interdisciplinary partnership research.

\section{Place of legumes in present and future farming and food systems}

2.1 Reasons why legumes occupy a low position in the French farming systems of the early twenty-first century

Since the 1950s, the proportion of grain and fodder legumes in French arable areas has considerably decreased, under the combined effect of the intensification of livestock farming, gradually relying on massive imports of soyabean, of a European political support for cereal productions and of an increasingly unfavourable climatic and parasitic context. These evolutions are similar in Europe, where legumes covered, in 2006, an average of only $3.3 \%$ of the agricultural area, as against more than $30 \%$ in the USA (Fig. 2). Consequently, most European and French plant protein requirements are covered by imports.

\subsubsection{Fodder legumes: a decline linked to the intensification of agriculture}

Historically in France, legumes were mainly cultivated for the production of protein-rich fodder. These crops were inserted into mixed crop-livestock systems because of their agronomic role with respect to nitrogen in the rotation. In the early 1960s, land under pure forage legume crops in France reached 3.3 million ha and accounted for $17 \%$ of arable land (Fig. 3). During the next 30 years, land under legumes decreased to below 400,000 ha. On the other hand, legumes were maintained in the pasture associations of temporary grassland, which remained relatively stable from the 1960s into the early twenty-first century (around 2.5 million ha, including 35 to $40 \%$ association with legumes).

The sharp drop, during the 1960s, of pure fodder legume surfaces was the result of the fodder revolution. This revolution was a response to the high demand in the postwar period for agricultural products and in particular meat products. In this context, pasture legumes were gradually replaced by maize silage and grasslands with mono-specific grasses abundantly fertilised. The massive use of synthetic nitrogen fertilisers, available at attractive prices, was encouraged and supported by agronomic research, and the role of legumes as a fertiliser in rotations was forgotten. This evolution coincided with an evolution of ruminant feeding systems gradually substituting maize silage and soyabean oil cakes for hay and lucerne proteins. The recourse to grass and maize silage, with higher energy value, offered the livestock farmer better fodder quality and security, at the same time reducing workloads. Indeed, harvesting legumes for hay was very labour intensive, with no appropriate machinery, and legume fodder is not very suitable for storing as silage, because of its low sugar content.

In addition, the context of raw material prices for animal feed became very unfavourable for winter rations containing legume hay (supplemented by cereals). Fodder legumes never benefited from Common Agricultural Policy support, but imports of soyabean benefited from protection regimes at the European Union frontiers, which involved a price differential that favoured the use of soyabean oil cakes. Finally, the reduction in fodder legumes in the cropping systems was accentuated by the geographical specialisation of farming production, which resulted in separating cereal areas from cattle-rearing areas.

\subsubsection{Grain legumes: a short-lived rise linked to developments in the Common Agricultural Policy}

Originally, grain legumes, or pulses, were mainly cultivated as a source of proteins for human consumption. In the early 1960s, these crops accounted for 161,000 ha in France 
Fig. 2 Percentage of grain legume crops in the total area of arable crops in the countries of the European Union in 2006. Source: UNIP

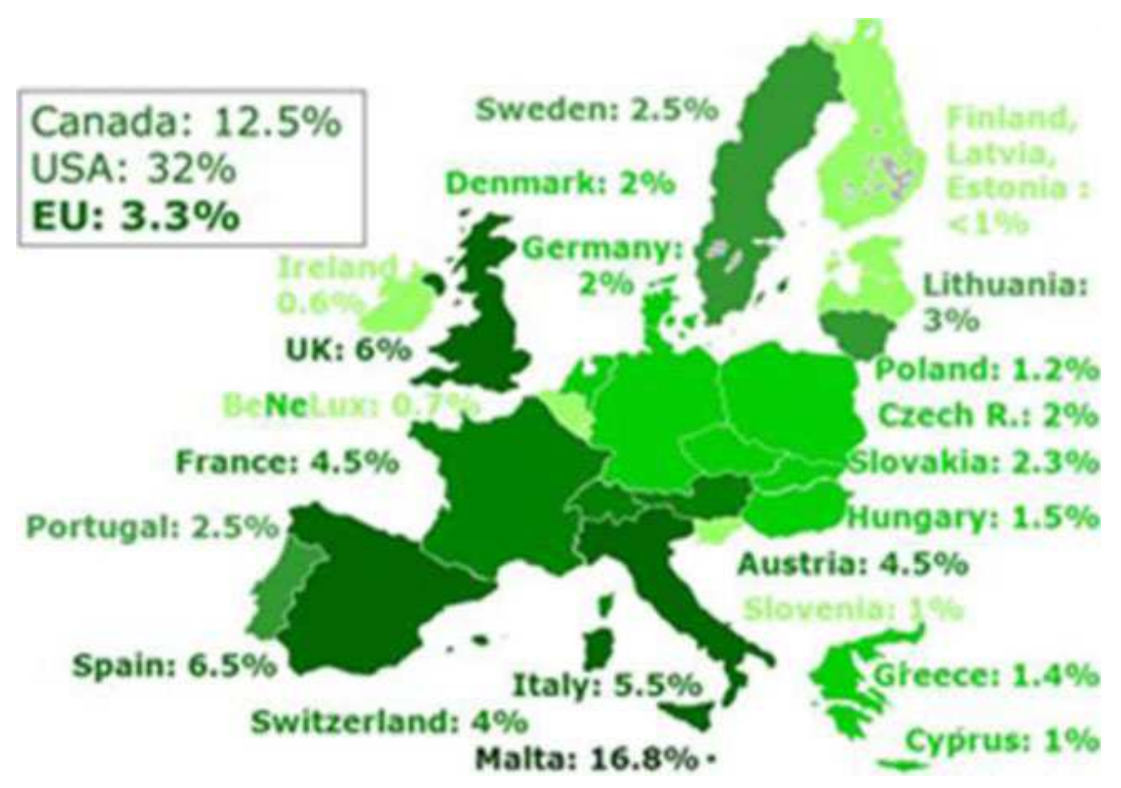

including $55 \%$ of green beans and $24 \%$ of broad beans and faba beans. With the evolution of diets incorporating more and more meat products, the annual consumption between 1950 and 1985 of grain legumes in France fell from 7.3 to $1.4 \mathrm{~kg}$ per person. After a sharp decline in the 1960s, these crops occupied no more than 60,700 ha in 1972 . Because of the virtual absence of political and economic support granted to dry vegetables, this production for human consumption was no longer officially recorded in France, with cultivated areas of less than 20,000 ha (average 2003-2007).

In the late 1970s, the European Community gave strong political support to the cultivation of grain legumes for animal feed. Following the soyabean embargo by the USA in 1973, Europe became aware of its dependence on American soyabean. American soyabean oil cakes were in fact the major source of protein-rich ingredients for animal feed. The structures set up in the 1970s by the Common Agricultural Policy supported the productions of protein-rich plants (the regulatory term including protein-rich pea, lupin and faba

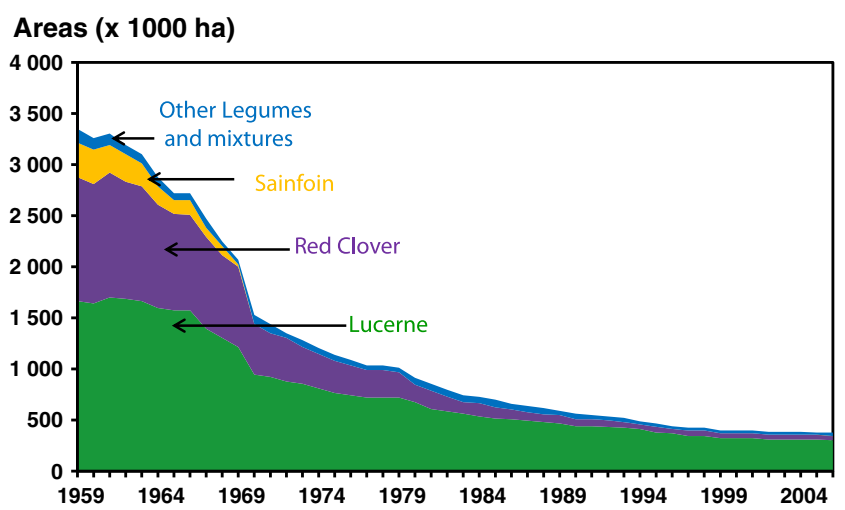

Fig. 3 Fodder legumes in arable areas cultivated in pure crops in France from 1960 to 2007 (source: UNIP) bean), guaranteeing competitive prices both for farmers and for processors. So, land under grain legumes increased in a spectacular fashion in the 1980s, with a prevalence in France of the pea which climbed to more than 700,000 ha in 1993, followed by the faba bean and the lupin (Fig. 4). Price support was accompanied by support for plant selection and the creation of agronomic references on their crop management. But since the early 1990s, land areas have continued to decrease, arriving at levels of about 100,000 ha in recent years. This evolution is closely connected to developments in the Common Agricultural Policy. In 1992, the decoupling of subsidies to agricultural producers brought about the end of price support for protein-rich crops, which were integrated into the field crop support system. As a raw material that can substitute for animal feed, the pea price is strongly linked to the price of the other raw materials: thus, as the pea provides formulas with more energy ( $\operatorname{starch} 45 \%$ ) than proteins $(21 \%)$, its price is positively correlated to the price of cereals and to a lesser extent to soyabean oil cake, with a price differential that proves to be fairly low compared to wheat.

The drop in prices led to a decrease in land area, and this fall in land area was made worse by instability of yields. Protein-rich crops in temperate zones are young species in terms of varietal selection even if 30 years of selection, primarily of the pea, but also of the faba bean, has significantly improved the yield and quality of the grains. However, yields arrive at a ceiling at a very much lower level than for cereals. This difference can be partly explained by the high intrinsic energy cost caused by biosynthesis of the proteins (MunierJolain and Salon 2005), but it is doubtless also due to lower investment in the selection of protein-rich plants. In addition, since the year 2000, yields under farming conditions have been very variable from 1 year to another. Because pea cropping has returned too frequently on fields with good yield 


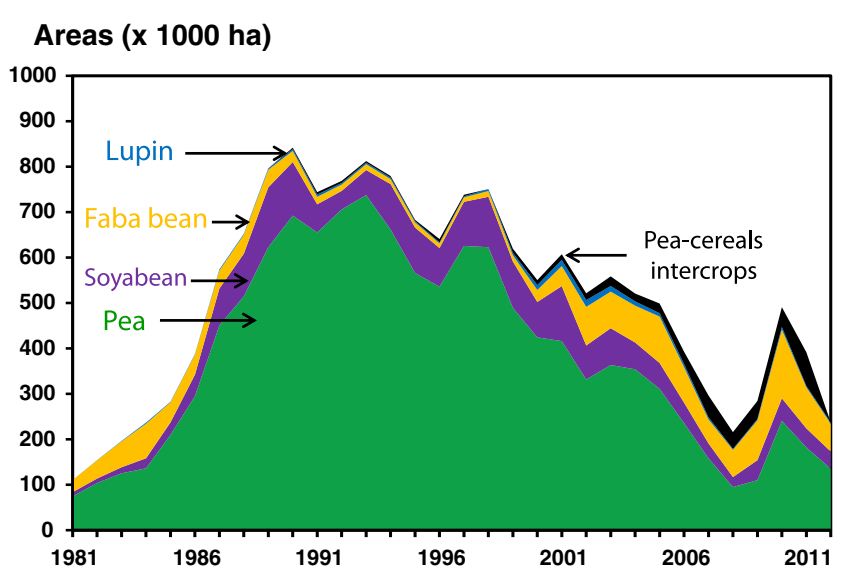

Fig. 4 Grain legumes in arable areas cultivated in France from 1982 to 2012 (source Agreste data, after Cavaillès 2009)

potential, some of this land has been infested with Aphanomycès $E$., a root disease that leads to strong yield losses (no protection exists against this fungus) and to the impossibility to grow pea the years after, once the field is infested. Although the pea crop has not disappeared from rotations, it has often been moved towards land that is not so good. In addition, yields in recent years have been considerably affected by the increasing frequency and intensity of thermal and water stresses related to climate change (Vadez et al. 2012). The high sensitivity of pea yields to those abiotic stresses can be explained by the fact that symbiotic fixation, resulting from a biological interaction between the plant and microorganisms of the rhizosphere, is particularly sensitive to biotic and abiotic stresses.

Thus, in the present climatic and regulatory context, in spite of the interest they have for agroecology, protein-rich crops have become risky and not very attractive for farmers. In conventional systems, farmers hesitate to grow legumes (Carrouée et al 2012), saying that they are too unprofitable compared to cereals and oilseed rape, on the basis of a calculation of the gross margin at crop level combining low yields with relatively low market prices. Yet, studies have shown that, at the cropping system level, the gross margin of a system including peas is not lower than that of a cropping system without peas (Carrouée et al. 2012). The low volumes thus produced do not make for very secure supplies for user industrialists, and they limit possibilities of segmentation and valorisation of quality. Associated with a relative lack of processing downstream, this results in grains of protein-rich plants being low-added value products which, from an economic point of view, are not very attractive for farmers.

\subsubsection{A deficit balance in protein-rich materials}

Grain and fodder legumes have a minor place in protein-rich raw material production (Fig. 5). And in spite of the increasing production of oil cakes as co-products of the bioenergy sector, France, like the rest of the European Union, still has a very negative balance in plant proteins. Animal feed is the principal outlet for grain legumes. However, the market for food for human consumption has progressed in recent years $(50 \%$ of the French pea harvest in 2011-2012; PROLEA data). Indeed, a market has recently developed for the export of whole grains to India (pea) and Egypt (faba bean) and for the industrial processing sector in France, Belgium and Scandinavia (Géhin et al. 2010). For industrialist users, the priority is to have a sector with a secure and reliable supply, able to provide raw material of constant quality. The poor availability of proteinrich grains on these markets is therefore a major problem for

\section{Materials Rich in Proteins in France (x $1000 \mathrm{t}$ of proteins)}

a 4000

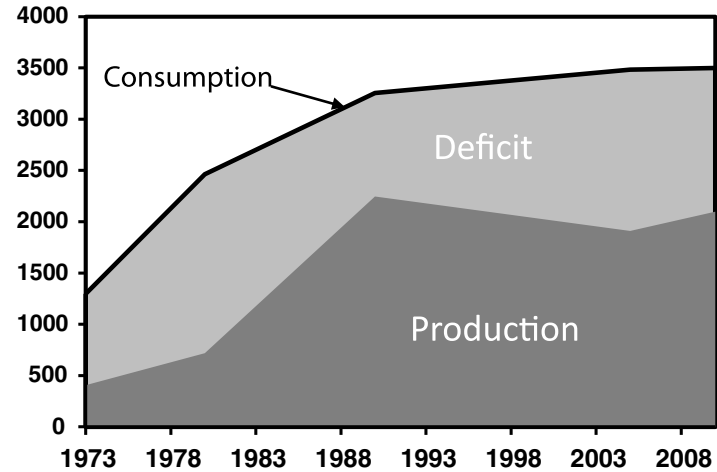

b

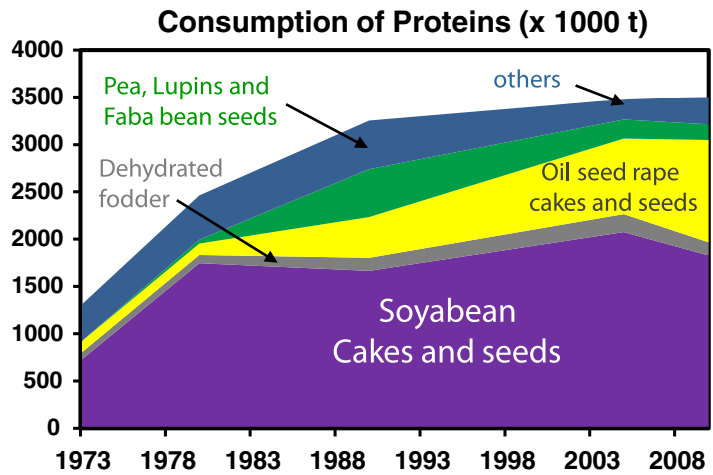

C

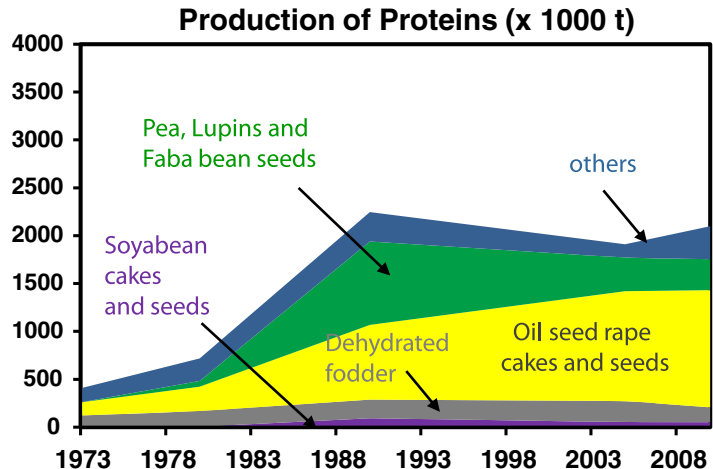

Fig. 5 Balance in materials rich in proteins in France. Balance between total production and total consumption (a) and details for the materials consumed (b) and produced (c). Material rich in protein are those with percent of proteins higher than $15 \%$ (except for milk powder). Others stands for meat and fich meals, residues of cereal distillers and miscellaneous materials. Data are from years 1973/1974, 1980/1981, 1990/1991, 2005/2006 and 2010/2011 (source: UNIP/ONIDOL) 
industrialists, with strong competition from soyabean imports, which cover most animal feed requirements. Indeed, soyabean oil cakes are easily available on the international market, and their performance in animal feed is in general higher than that of European protein-rich plants because of their high protein content, low variability and more digestible proteins. Finally, the supply of soyabean oil cakes is less scattered geographically than for the pea. Similarly, with low levels of consumption, France still has a significant deficit in dry vegetables for human consumption (in particular for lentils, dry beans and chickpeas), with an average domestic supply rate of only $27 \%$ over the 2001-2008 period. A challenge for the French market is thus to reduce its dependence in protein at various scales, from the farm to the territory.

\subsubsection{A lock-in of sociotechnical systems}

The weak position now occupied by legumes in rotations, both in arable and in cattle-rearing areas, appears related to various closely overlapping factors. Research towards increasing the productivity of soil and work has diverted farmers from these species, the more so because external resources were available to compensate for them (soyabean oil cakes in compound feed for animals, mineral nitrogen fertilisation to replace symbiotic nitrogen input). As they did not occupy much land, legumes only benefited from limited investment as regards varietal selection compared with the dominant crops (wheat, maize, oilseed rape), which contributed to their profitability deficit. Much greater effort was also expended on these dominant crops in terms of experimentation and creation of agronomic references, and they were prioritised in the organisation of collection logistics. The active networks, innovations and acquisitions of key skills which accompanied the structuring of major crop sectors provide them today with many assets to strengthen their competitive position on the markets (Meynard et al. 2013). The development of legumes under these conditions is confronted by a real "lock-in" of the sociotechnical system. The concept of technological lock-in indicates situations where, even though technology judged to be more effective does exist, the technology originally selected remains the standard because the entire system was organised around it; consequently, it seems difficult to change it (Arthur 1994; Cowan and Gunby 1996). The lock-in of a production system leads to selection between innovations: those which are completely compatible with the benchmark technology have a chance of developing, whereas those which call into question either this benchmark, or the relationships organised around the benchmark, are much less likely to develop. Lockin does not result from a deliberate strategy by one of the stakeholders, but on self-reinforcement mechanisms which are created around a technological solution (Fares et al. 2012). Although the interest of developing legumes is admitted by everyone, they still remain marginal because production systems, processing industries and sectors were progressively organised, then strengthened, without them. For example, the rapid expansion of pea crops was accompanied between 1980 and the year 2000 by research into the splitting of grains and the properties of the components (starch, proteins, fibres) for human consumption and non-food uses (Vose 1980; Guéguen 1983; Colonna et al. 1985; Lourdin et al. 1995). But even if these studies showed the potential interest of these grains for the processing industry, industrial developments remained limited (Géhin et al. 2010). And the core skills of the present agricultural system are structured around a set of shared routines, not only in the choice of species and management sequences in plant production, but also in the choice of diet formulas in livestock production. Overall, this is to the disadvantage of legumes. For example, the challenges of reducing nitrogen fertilisers lead more naturally to incremental innovations, such as seeking for a more precise adjustment to crop requirements of doses and application dates (e.g. the Farmstar arrangement, Labarthe 2010) than redesigning a cropping system that introduces legumes into the rotation. The stakeholder networks also contribute to lock-in, insofar as none of them are interested in changing their behaviour as long as the others do not change. Whether they are researchers, politicians, industrial leaders or union representatives, their position in the institutions and their interconnection contribute to aligning their choices in favour of a shared technological paradigm in which they each find advantages (Vanloqueren and Baret 2009). It is this highly consistent organisation of sectors upstream and downstream, and the creation of benchmarks and technical advice, which slows down the development of legumes.

2.2 New issues in the development of legumes in the context of agroecological transition

\subsubsection{From a demographic issue to a nutritional issue}

In 2050, world agriculture will have to meet the food needs of nine billion individuals, while guaranteeing more sustainable productions. The "Agrimonde 2050" foresight study (Dorin et al. 2011), which couples problems of agriculture and food at the global scale, has been used here to specify the place which could be occupied by legumes in future farming and food systems. Two scenarios have been put forward (Fig. 6): the first scenario (AG0) prolongs the historical of growth, production and consumption of food calories in each region of the world (Fig. 7), and in the AG0 scenario, the apparent food availability thus reaches $3,588 \mathrm{kcal} /$ inhabitant/day at global level in 2050, of which $23 \%$ is of animal origin. This scenario shows a consumption of animal products which continues to grow and significant inequalities between regions 


\section{Production of food calories from plant origin (Kcal.ha-1.day ${ }^{-1}$ )}

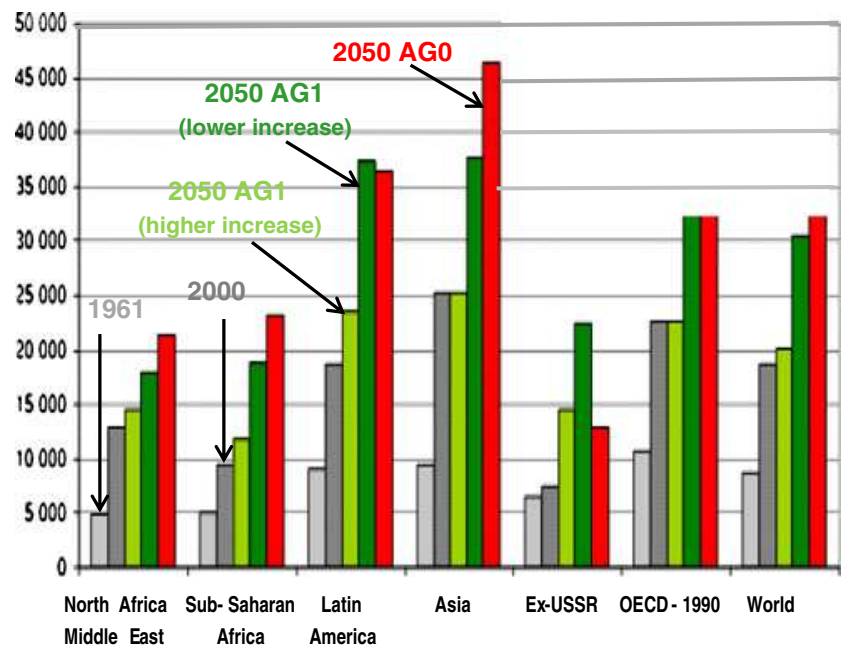

Fig. 6 Production of food calories from plant origin (kilocalories per hectare per day) in different regions of the world in 1961, 2000 and 2050, for several Agrimonde scenarios: AG1 scenario: considering that land reserves are limited in Asia, OECD-1990, North Africa and Middle East, the food production yields could not be significantly increased in the 2000-2050 period (lower increase hypothesis, 0 to $20 \%$; higher increase hypothesis, 40 to $50 \%$ ). For Latin America and sub-Saharan Africa, both still unused land reserves and improved yields could lead to food production gains comprised between $30 \%$ (lower increase hypothesis) and $100 \%$ (higher increase hypothesis). In the Ex-USSR region, a spectacular increase is observed: the yields are either twofold (lower hypothesis) or threefold (higher hypothesis) increased. AGO scenario: scenario that prolongs the historical evolutions of growth, production and consumption of food calories in each region of the world, as established on the basis of the "global orchestration scenario" of the Millenium Ecosystem Assessment (adapted from Dorin et al. 2011)

of the world. In the second scenario (AG1), the levels of income and food consumption are partially decorrelated

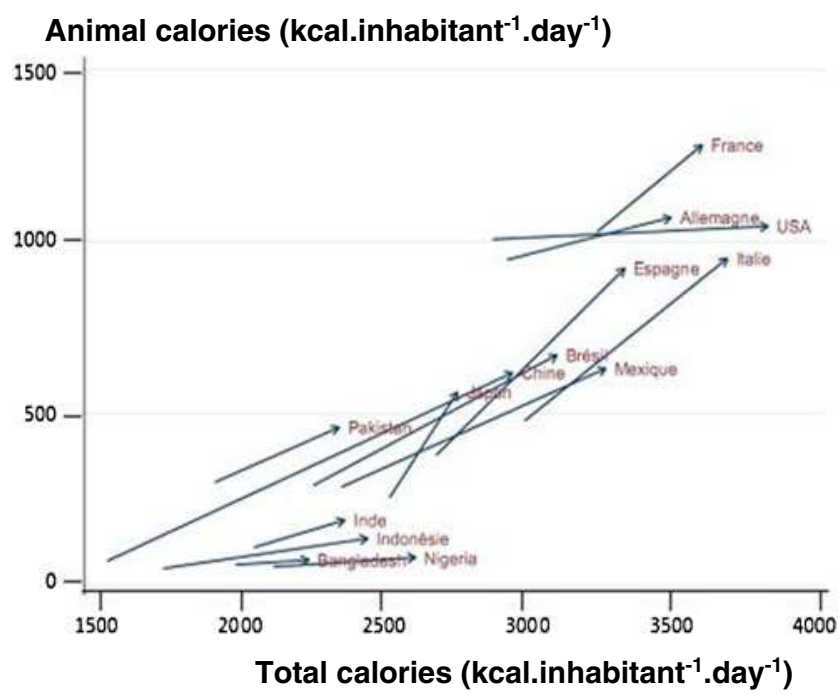

Fig. 7 Variation in the availability of calories from animal origin versus total calories, from 1961 to 2005 (from starting point to the end of the arrows): some examples in the world, as established using the FAO data (adapted from Esnouf et al. 2011) because of concerns of health, equity and environment. This scenario leads to a hypothetical average food availability of 3 , $000 \mathrm{kcal} / \mathrm{inhabitant} / \mathrm{day}$ in all the regions of the world, of which only $16 \%$ is of animal origin (Esnouf et al. 2011). This scenario implies that availabilities in total calories and animal products decrease sharply in the OECD countries $(-25$ and $-50 \%$, respectively) and are increasing very significantly in sub-Saharan Africa.

These two scenarios suppose major changes, which vary according to the regions of the world, not only in terms of yield (Fig. 6), water management, cropping practices and sustainability, but also of dietary habits. According to both of these scenarios, world demand for calories of animal origin is likely to increase; according to AG0, in many regions of the world, following the global increase in the availability of total calories; according to AG1, in some countries of Asia and sub-Saharan Africa, reaching the threshold of $500 \mathrm{kcal} /$ inhabitant/day, this increase in demand for animal protein could lead to an increased demand for protein-rich raw materials, including protein-rich plants, for the animal feed sector. In the AG1 hypothesis, reduced consumption of animal proteins in OECD countries should induce an increasing substitution for animal proteins by new sources of proteins including plant proteins (Boland et al. 2013), both for nutritional uses and as techno-functional ingredients (texturing, emulsifying, foaming, etc.) in the formulation of food by the agri-food industry. This evolution should encourage the consumption of grain legumes and their protein-enriched derived products; it could also benefit from growing awareness in these populations of new health issues related to the increase in so-called civilisation diseases, as well as from the lower economic, energy and environmental costs of producing plant proteins. These prospects can offer new outlets to legumes, both in direct consumables and in processed products. Legumes could benefit from a demand for products meeting needs for pleasure, health, convenience and naturalness, which are developing considerably in Western lifestyles. Outside catering, which progresses regularly, and school meals are still market segments where dry vegetables could be better used, based on the recommendations of the French National Nutrition and Health Plan (PNNS). In addition, lower consumption of animal products could bring about new requirements for the sensory, functional and nutritional quality of legume by-products.

\subsubsection{Ecological challenges}

Taking environmental challenges into account leads Western society to design more sustainable production systems, to reduce their negative impacts on the environment, to manage the scarcity of certain resources (water, fossil fuel) and to adapt to climate change. For this, new, more efficient and environmentally friendly farming practices must be adopted. 
Faced with this challenge, legumes have a significant role to play (Jensen et al. 2012), as illustrated in Fig. 8.

Because of their capacity to fix air-borne nitrogen, legume crops do not require nitrogen fertilisation. So, their introduction into cropping systems makes it possible to reduce nitrogen fertiliser inputs. The mineralisation of their crop residues enables nitrogen fertilisation of the following crop to be reduced too. Thus, the recommendations to reduce the nitrogen application after pea can be an average of 20 to $60 \mathrm{~kg}$ $\mathrm{N} /$ ha for wheat and 30 to $60 \mathrm{~kg} \mathrm{~N} / \mathrm{ha}$ for oilseed rape, for an equivalent or higher yield (Carrouée et al. 2012). This reduced nitrogen fertilisation contributes to reducing the greenhouse gas emissions (Nemecek et al. 2008; Jensen et al. 2012; Fig. 8): carbon dioxide emitted during the production of fertilisers (Haber-Bosch process) and nitrogen protoxide $\left(\mathrm{N}_{2} \mathrm{O}\right)$ emitted during spreading. Moreover, legume crops and their residue mineralisation have $\mathrm{N}_{2} \mathrm{O}$ emission levels similar to unfertilised non-legume crops (Jeuffroy et al. 2013; Rochette and Janzen 2005; Jensen et al. 2012). The contribution of legumes to reduce greenhouse gas emissions (thus to mitigating climate change) and to limit the exhaustion of fossil fuels can therefore prove to be very important. Given also that to produce 1 animal calorie from chicken or pig requires 4 plant calories and 11 calories in the case of beef (FAO 2009), a greater substitution for animal proteins by plant proteins in human food can be an additional major instrument in the reduction of greenhouse gases.

Other ecosystem services rendered by legumes deserve to be considered, such as improvement of the soil structure, diversification of rotations, disruption to telluric pathogen cycles and reduced leaching of nitrates in the case of perennial legumes with deep root systems (Jensen et al. 2012). A perennial legume used primarily by cutting, such as lucerne, encourages avian biodiversity at territory level (Berthet et al. 2012). Nevertheless, there is the question of remuneration for these ecosystem services and the role of public policies in this remuneration. Some services are intended for agriculture (biodiversity supporting pollination and beneficials), others serve society (limiting pollution), some of these services are directly remunerative for the farmer (savings in nitrate fertiliser) and others are not (limiting pollution).

Finally, legumes are particularly important in organic farming; indeed, in these systems, they are an essential instrument ensuring nitrogen balance in farms, particularly in systems with no livestock, which have a chronic deficit in nitrogen availability (David et al. 2005). However, under organic farming conditions, many biotic and abiotic factors are a considerable limitation on legume yields (Hellou and Crozat 2005).

\subsubsection{Challenges for the territorialisation of resources}

The decline of legumes is linked to the development of the use of chemical inputs, to the dynamics of regional farming specialisation and to the establishment of long industrial circuits. The decline in land areas under fodder legumes accompanied the retreat of mixed crop-livestock systems. The intensive livestock farming areas, concentrated in the

\section{$\%$ reduction compared to control cropping systems without pea}

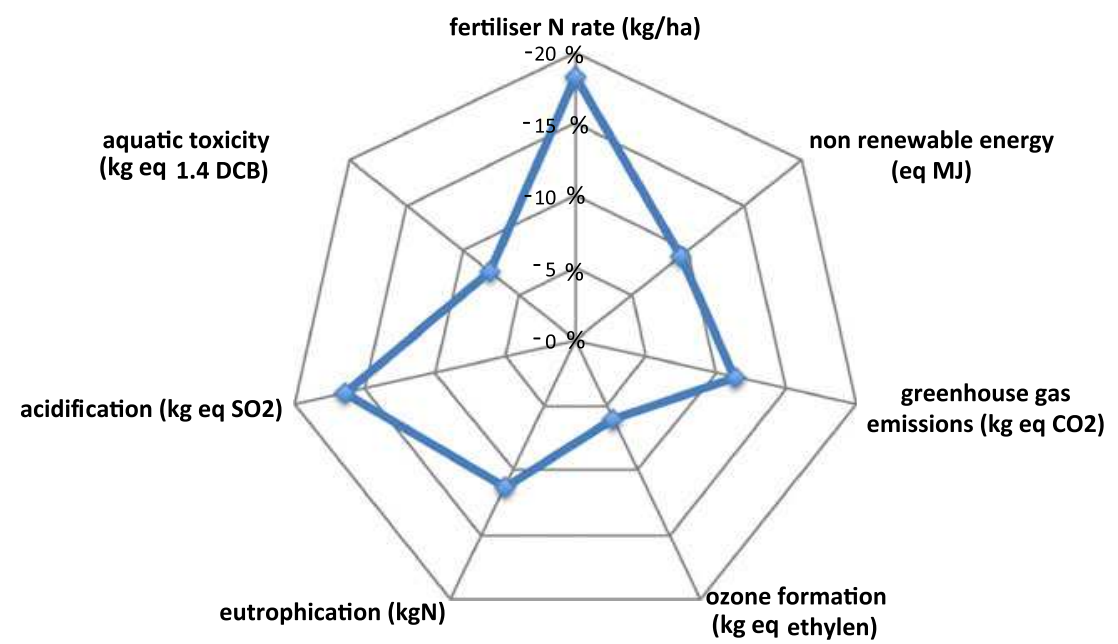

Fig. 8 Reduction (in percent) of the environmental impacts of cropping systems including a pea crop in comparison with cropping systems without pea. Results (percentage of reduction from the control cropping systems of the same region) are from life cycle analysis applied to 27 cropping systems including pea (in three French regions: ten in Beauce, eight in Bourgogne, nine in Moselle) and ten control cropping systems (three in Beauce, two in Bourgogne, five in Moselle). The crop management on all the crops of the rotations was simulated using the description of the cropping systems (control and alternative) made by several experts in each region. Simulated cropping systems were optimised in taking into account the effects of the preceding pea crop (adapted from Carrouée et al. 2012) 
north-west of Europe, are close to the factories where concentrates are manufactured, themselves located close to ports (where massive quantities of soyabean oil cakes arrive) and not in regions producing protein-rich crops. On the other hand, it can be imagined that the search by farms for greater autonomy in nitrogen, the return of livestock farming to areas of field crops or the development of short circuits might encourage a revival of legumes. Such territorial dynamics, for the production and local use of legumes, were identified when peas were grown to feed monogastric animals (e.g. in the Burgundy region, Petit et al. 2012) or lucerne hay produced to feed ruminants (e.g. in the Poitou-Charentes region; E. Berthet, personal communication). However, current economic trends are not going in this direction (Chatellier and Gaigné 2012): the search for economies of scale and the huge increase in the price of cereals tend to accelerate the abandonment of the livestock activity by mixed farms. A return to territorialised farming productions could nevertheless be encouraged not only (a) by strong public policy choices (agricultural policies aimed at the diversification of rotations and cropping plans, support for the emergence of local sectors ensuring the development of employment, etc.), (b) by an increase in the cost of energy (search by farms for energy autonomy, reducing transport costs) and (c) by the search, by industrialists, for secure supplies based on contracts with local producers, but also (d) by a demand for traceability and social links encouraging the development of short circuits (Lamine 2005) and quality signs. The development of official signs and designations of origin does ensure for the consumer a certain quality based on production practices under specifications (Allaire 2012). In the face of the highly standardised products from industrialised food production, new distinctive signs are emerging which make best use of specific territorial resources and which strengthen consumer confidence. More local consumption of legumes as animal feed or human food could contribute to designing more sustainable processing and consumption systems in the territories (Muchnik and de Sainte Marie 2009), many of which could consider cultivating legumes because of their wide variety. The redeployment of these crops is likely to stimulate the development of new processing and marketing activities, generating employment and wealth in the territories, depending on the added value that could be achieved from these new outlets.

\subsection{What instruments are there to encourage transition} towards production systems integrating more legumes?

The combination of contemporary demographic, environmental and economic challenges calls for a new agricultural transition, qualified as agroecological transition, in which legumes could have a significant role to play. However, the lock-in of current farming systems limits the possibilities of adopting new crops such as legumes. But, the multi-level approach of the theory of transitions (e.g. Geels 2011) indicates that new systems can detach themelves and emerge to support the introduction of legumes into the farming systems of tomorrow.

\subsubsection{The instruments for unlocking}

On one hand, contemporary orientations of the demographic, social, political, economic and environmental context or "sociotechnical landscape" (Fig. 9) can put pressure on the dominant "sociotechnical system" (excluding legumes), for example via the introduction of new regulatory measures. Thus, the "greening" of Common Agricultural Policy supports, within the framework of the 2014-2020 reform, conditions part of the supports to respect for a criterion of rotation diversification; this rule could encourage diversification crops such as legumes. On the other hand, small networks of actors attentive to contemporary orientations can come up with "niche" innovations that satisfy society expectations. Those working in niche markets are not locked in by the routines and standards of stakeholders in the dominant system because they are outsiders or on the margin of the dominant system; this enables them to make more radical innovations, without mobilising the same bases of knowledge and skills. The range of innovations is wide: they can be purely technological, but can also relate to new procedures, organisations, standards, new products, etc. Certain innovations originating from niches can be disseminated gradually to the dominant system which, after a transitional stage, is then unlocked.

All of the niches may not be destined to develop, but some of them can be springboards for beginning transitions with the dominant sociotechnical system. These transitions lead to the production of technologies, products, standards, etc., which will no longer be those of the system in place, nor those proposed by the niche markets, but are the foundations for the new, hybrid system. For example, the organic farming niche conveyed the idea that it is beneficial to reduce the use of synthetic products in favour of natural products. This thought leads processing industrialists today to develop socalled clean label strategies. These strategies adopt the same principles as organic farming in the transformation stage, replacing preserving agents and synthetic colouring by natural by-products. However, for the moment, no official label clearly displays this approach.

\subsubsection{What added value is there to support new niches encouraging legumes?}

A revival of legume cropping in the territories supposes that it will generate adequate financial returns associated with economically viable outlets. This added value surplus can emanate from two major innovation logics in the 
Fig. 9 The multi-level perspective on transitions, adapted from Geels (2011)

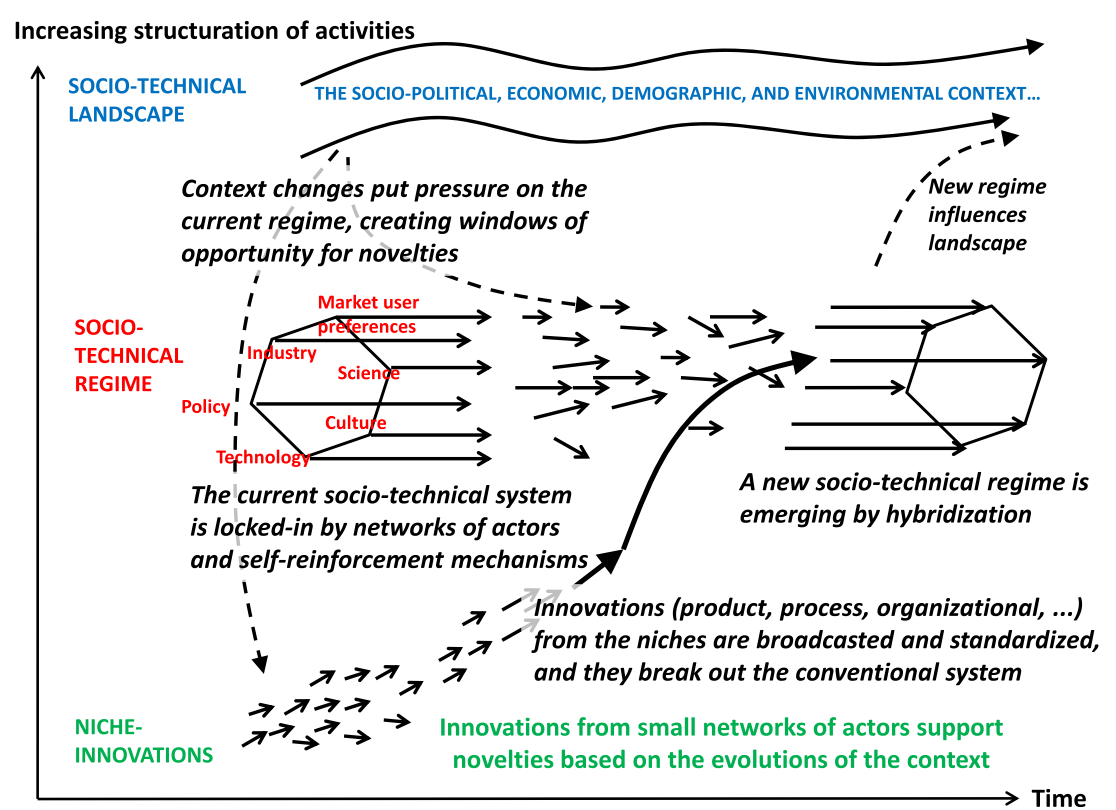

differentiation of products on the agro-food markets. One corresponds to diversification in the composition of the products, the other to the promotion of identity characteristics (Allaire 2012). Valorisation of these innovations through the link with the territory could give legume crops a new economic attraction, initially locally, then ultimately to encourage their long-term establishment.

The first strategy can apply to the development of a segment called as "processed plant proteins", with a link to the territory in a cost-cutting logic. The purchase of raw materials on international markets, more unstable and less standardised, requires a series of intermediate controls. The costs incurred by these controls, in addition to higher intermediate costs of storage and routing, can ultimately result in high transaction costs for the processors. This strategy can concern split grains and derived products either enriched in proteins, starch or fibers, for use as ingredients in the food industry or for nonfood uses (Guéguen 1983, 1999; Géhin et al. 2010). It can also apply to use as a whole plant for fodder, biofuels and green chemistry. This strategy stresses the functional quality of the product, whether nutritional or technological. It is based on data of composition, physicochemical properties and component structures.

The second strategy can be complementary to the first, promoting specific local expertise, developing the diversity of legumes. This strategy is already developed for the food market (in France, more than $30 \%$ of dry vegetable production is marketed under official quality signs and around $20 \%$ under private quality signs). This proportion is clearly lower for legumes intended for livestock. This strategy could be qualified as a "return to sources", with a link to the territory in a specific quality logic; it can satisfy the expectations of consumers seeking local products indicating various forms of quality (organoleptic, environmental, health, etc.).
For these two strategies, the food industry and the commercial sector have a major role to play in the evolution of consumer behaviour, through the development of products and the creation of these niche markets, supported by private or public labels (Fig. 10). At the biotechnical level, the development of these new markets relies on significant efforts of innovation as regards product processing; technological innovations in particular can make up for "defects" in the quality of agricultural products. At the economic level, the challenge for territorial stakeholders is to help the reduction of transaction costs by developing new coordination methods guaranteeing product quality. Thus, in France today, an increasing number of contracts between industrialists and farmers can be observed for some of these outlets. These contracts make it possible for industrialists to improve the quality control of their supplies (obligation of traceability, respect for standards) and to improve their legibility concerning availabilities and prices.

\section{New research questions about legumes in the context of agroecological transition}

In the light of the analysis developed above, four major groups of research questions on legumes have been identified.

\subsection{Analysing the lock-ins and identifying instruments} of transition towards systems integrating more legumes

This involves identifying the drivers of innovation and change likely to go beyond short-term economic logics which lead to the lock-in mentioned above. Clarifying the selfreinforcement mechanisms that lead to lock-in is the first 


\section{Lentils areas and Labels* in France (2010 data)}

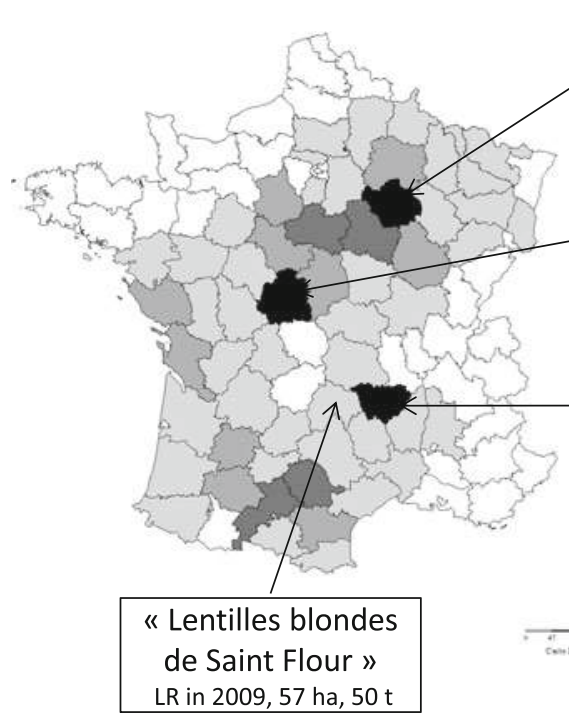

Dried and semi-dried beans areas and Labels* in France (2010 data)

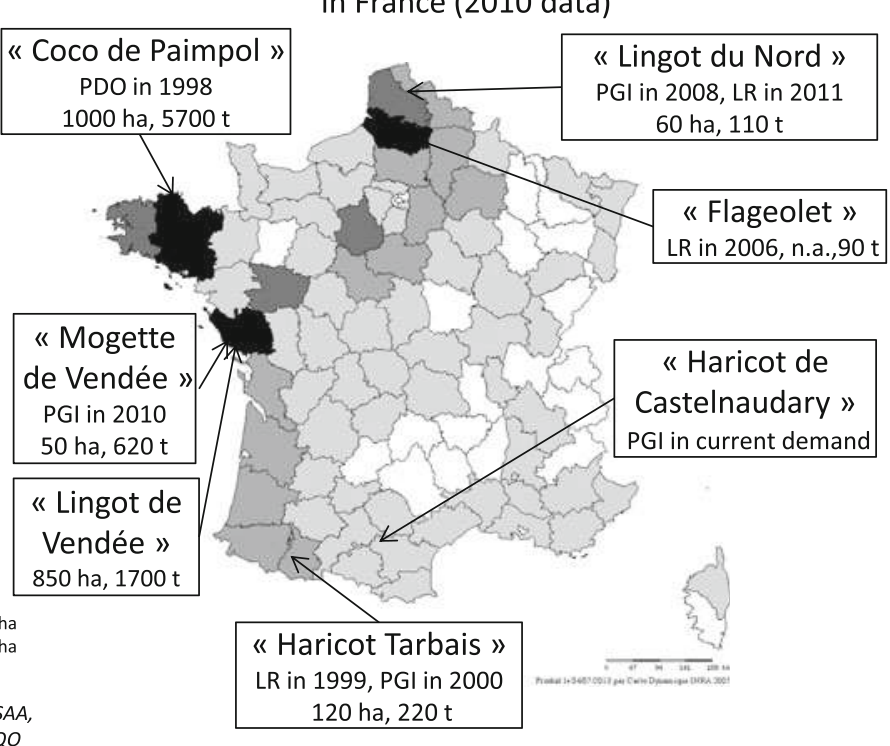

PDO: Protected Designation of origin ; PGI : Protected Geographical Indication ; LR Label : « Label Rouge »

Fig. 10 The maps indicate the conventional land areas with cultivated lentils or dried/semi-dried beans in 2010 in the French departments (administrative delimitation). Legends within squares indicate-where exist - the public labels with the date of their obtention and the area and volume of those specific productions in 2010. Among those labels, we distinguished here (a) labels relative to the geographical origine according to the European certification: protected designation of origin $(P D O)$ and protected geographical indication $(P G I)$ and (b) "Label Rouge" $(L R)$ label, a French specification on a high-quality process of production stage. A recent study (Meynard et al. 2013) showed that insufficient structuring of the sectors and of the coordination between actors, from downstream to upstream, was a major cause of the failure to build or develop some diversification sectors. Further thorough research will be necessary to propose unlocking methods. It would seem essential to reflect on the various potential uses and outlets for legumes and understand which niche markets might stimulate their revival in the sociotechnical farming system, thus contributing to the transition of European agriculture towards greater sustainability. Analysing the various methods of coordinating stakeholders in the mobilisation of specific market instruments can help to define the structuring of new legume sectors. Generally speaking, it appears essential to understand innovations at sector level because a combination of agronomic, technological and organisational solutions is often necessary to manage production variability and quality.

Enhancing the value of the environmental quality of legume crops or the nutritional quality of legume proteins will involve the exploration of a diversity of public policy instruments. Indeed, public policies can change the direction of trends by financial incentives. With this in mind, research will have to combine economic and sociological analysis of actors. The agroecological analysis of innovative production systems supposes an assessment by multi-actor, multi-criteria and multi-scale approaches. The multi-criteria analysis must include economic and sociological dimensions, as well as criteria to assess the resilience and flexibility of the systems. These approaches ask methodological questions on the definition and weighting of the assessment criteria. The association of stakeholders, innovators and experts is a major challenge. It involves not only exploring and exploiting the diversity of the actors, but also associating them with the dissemination of innovations and the assessment of innovative solutions (in particular for the definition and weighting of the assessment criteria).

\subsection{Identifying new and diversified outlets for legumes in a sustainable production chain}

The transition theory (Geels 2011) offers prospects for unlocking by showing that even if the dominant farming system slows down the adoption of some practices, these practices can be adopted by actors seeking differentiation on the market. Diversifying legume outlets, in particular through niche markets with higher added value, could therefore contribute, via processes of dissemination and hybridisation with the conventional system, to making the farming system evolve in their favour. In addition, the emergence of these outlets can be supported by public policies. New outlets therefore deserve to be studied. 


\subsubsection{New outlets for food}

The consumption of legumes can be a response to new issues associated with the rebalancing of food regimes, at individual and planetary scales (Leterme 2002). If the aim is to modify eating habits, the consumer has to be offered a diversity of products with a less old-fashioned image and more practical to cook. Indeed, unlike cereals for which there is a multiplicity of processed products, little effort of technological innovation has so far succeeded in creating a range of diversified products from grain legumes. Efforts in this direction are currently being carried out in Canada (Fig. 11). The definition of the "health" value of these grains has to be improved to promote their uses in the human diet. However, "unlocking" new uses can require backing from public authorities to support the downstream activities in innovative approaches. Through the French National Nutrition and Health Plan (PNNS), public authorities provide the opportunity of signing charters with professionals of the agri-food sector who are commited to improving the nutritional profile of their products. For example, the Bleu-Blanc-Cœur sector which specialises in the supply of meat and milk whose omega fatty acid composition is improved by incorporating grains rich in alpha linolenic acid into the feed intake (Lessirard 2009). So, this private label supports the production of flax, lucerne, lupin and faba beans.

\subsubsection{New outlets for the extraction of high added value compounds}

Industrialists are potential customers for protein fractions of plant origin, fibres and starch; and there are processes for the fractionation of legumes and the use of the various fractions for food or non-food applications (Géhin et al. 2010) (Fig. 12). Whatever the purpose of the use, the fractionation processes have to be optimised by integrating the variability of the raw materials. To develop non-food uses, research on the technofunctional properties of biopolymers (starch, fibres, proteins) must be intensified (Lourdin and Colonna 2006; Guilbert et al. 2006; Axelos et al. 2006). To penetrate the market of ingredients for food, it is imperative to overcome some stumbling blocks: (1) sensory, by limiting even eliminating the presence of undesirable tastes and odours (Heng et al. 2006a,b); (2) functional, for better complementarity and/or competitiveness with respect to other sources of proteins (milk, soyabean, wheat); and (3) nutritional, via the identification of the biological and nutritional properties of these ingredients, in particular of fibres and proteins (Anderson and Major 2002).

Whether it concerns whole grain or derived fractions, knowledge still needs to be acquired on the environmental and genetic determinants of the functional and nutritional quality for various food uses and to reflect on the use of dedicated varieties. These quality criteria, specific for fractionation and food agro-processor industries, have never been taken into account in genetic improvement programmes.

\subsubsection{New outlets for the production of bioenergy}

Legumes may play a particular role in the production of biomass for bioenergy; they improve environmental balances because the biological fixation of atmospheric nitrogen reduces the need to use nitrogen fertiliser. New uses of legumes are therefore possible as whole plant to produce biomass for bioenergy (Thomsen and Hauggaard-Nielsen 2008; Jensen et al. 2012). The improved use of crop co-
Fig. 11 Exemple of efforts made in Canada to enhance the consumption of legumes in food regimes (source:

www.pulsecanada.com)
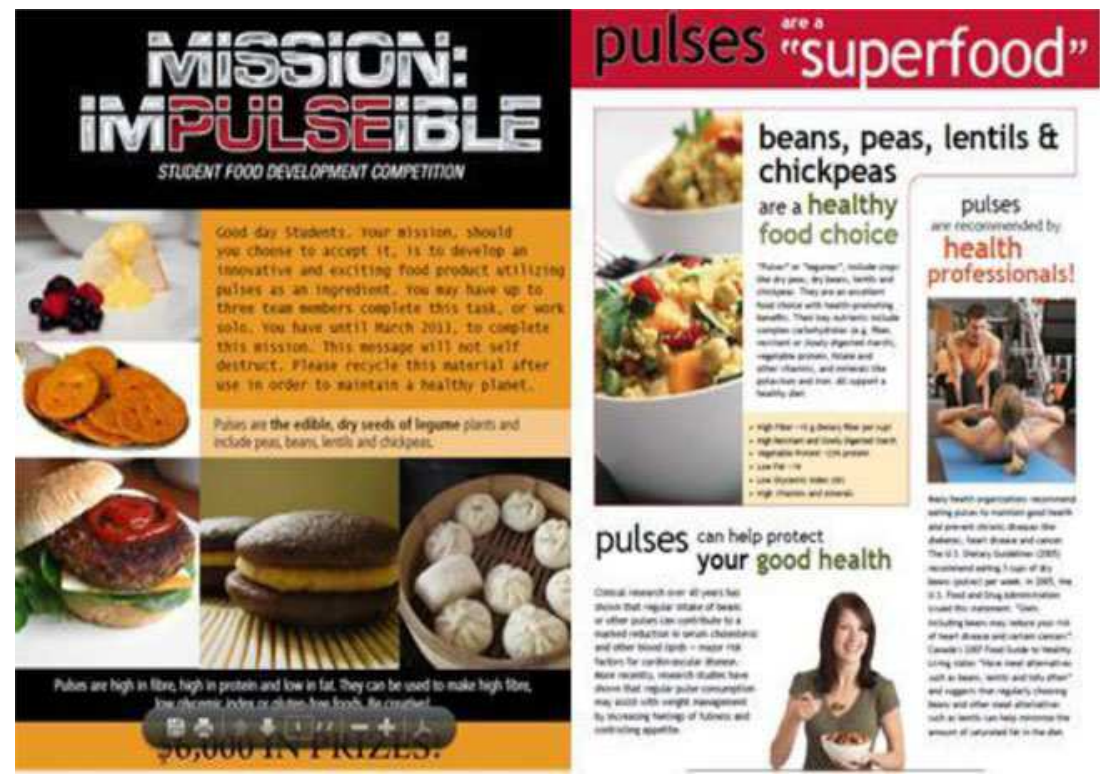
Fig. 12 Main processes for preparing plant protein-enriched products from starchy legume seeds. Dry process (process 1): protein concentrate obtained by air classification. Wet processes (processes 2 and 3): protein isolates obtained by isoelectric precipitation (1) or by ultrafiltration (2)

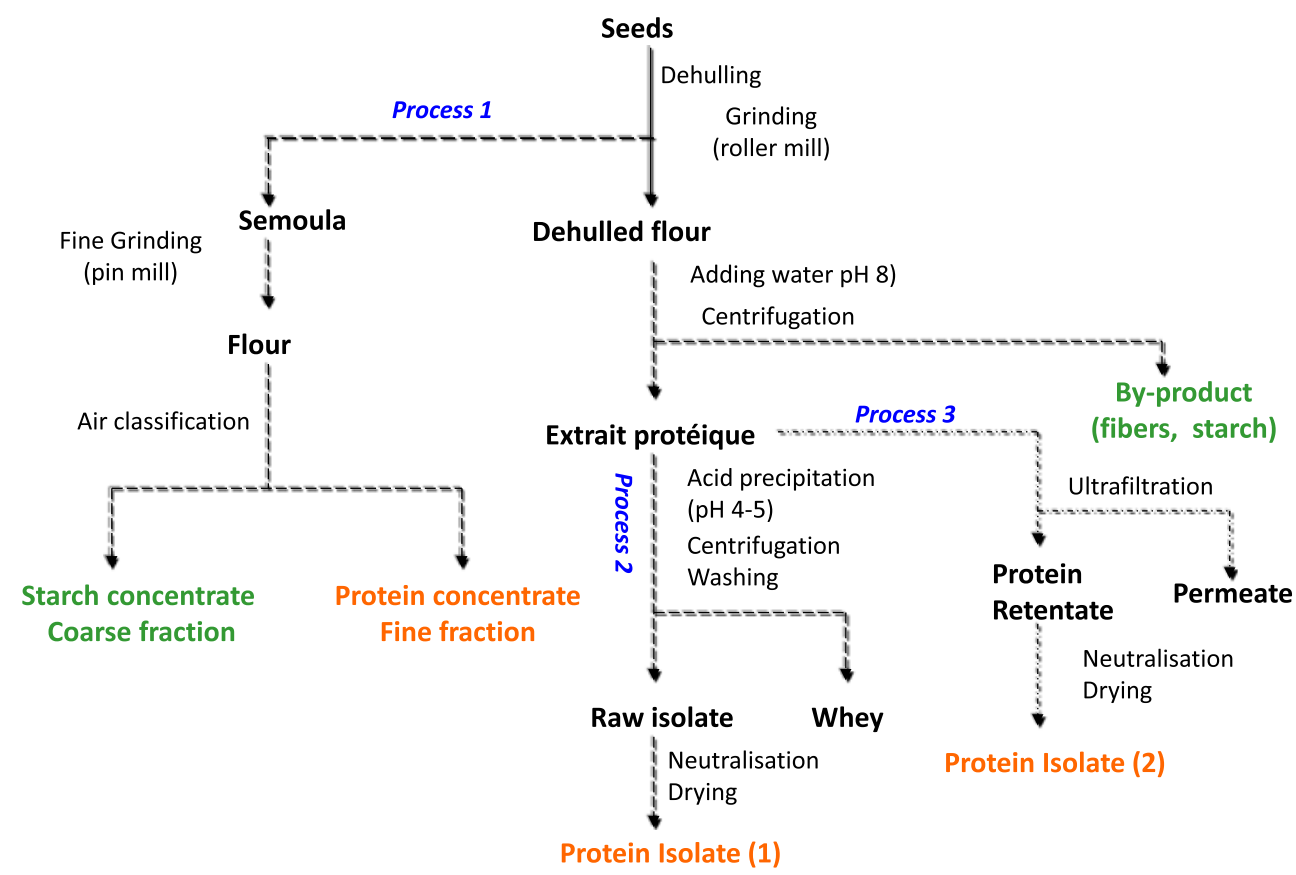

products can also be envisaged: for example, the use of lucerne stalks for the production of bioethanol, using the leaves as fodder (Lamb et al. 2007). At the levels of cropping systems, territories and sectors, the challenge is to integrate legumes (intercropped or not) as an alternative to dedicated perennial crops (coppice, miscanthus). Annual or multiannual crops have the advantage of forming part of traditional cropping systems, thus allowing greater flexibility, diversification of crops in the successions and conservation of part of the rotation dedicated to human food and animal feed. Work must include thorough environmental assessments at sector level and integrate the question of disseminating the innovation into cropping and processing systems.

However, legume crops can have some limits (Jensen et al. 2012). Firstly, the use of legumes to produce biomass can limit their contribution to soil fertility by ploughing in the residues; this contribution is reduced if the whole plant is harvested for bioenergy outlets. In addition, even if the fossil energy needs per quantity of dry matter are low, the outputs are low too compared with other dedicated species. Finally, the quality of the legume biomass is less well adapted to certain processes. Nevertheless, there are still very few data today concerning this quality, and these data are variable among species and according to references (e.g. Petersson et al. 2007; Martin et al. 2008; Thomsen and Hauggaard-Nielsen 2008). Legumes intercropped with grasses (Fig. 13) can enable some limits to be lifted, such as productivity (Jensen et al. 2012) or quality control to match the biomass to the processing processes. Intercropping deserves to be studied for this use. Identifying the most appropriate species and varieties of legumes as well as perfecting their management are important issues to fulfill the requirements of industries for the various processing procedures. With this in mind, it is essential to look further into links with industrialists holding technological solutions in processing procedures.

3.3 Assessing the ecosystem services provided by legumes at production system and territory scales

\subsubsection{Assessing the services at wider scales}

The symbiotic fixation of atmospheric nitrogen means that legumes are essential components for improving the efficiency of plant production systems with regard to nitrogen (Jensen and Hauggaard-Nielsen 2003). Moreover, the reduction in nitrogen fertiliser use, made possible by these species, has positive

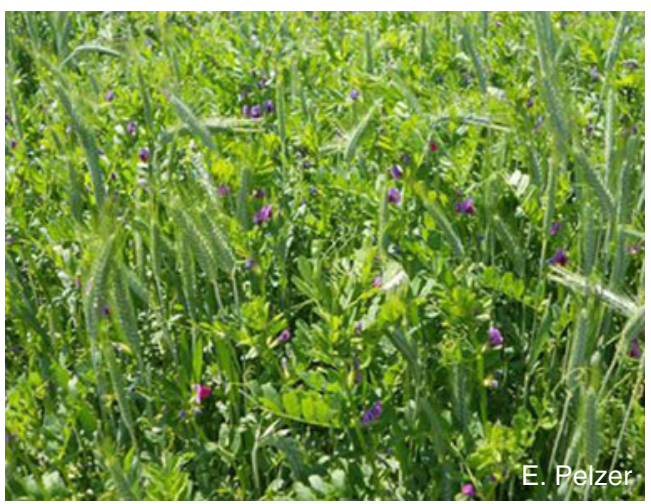

Fig. 13 Triticale-vetch intercropping for biomass production dedicated to bioenergy. E. Pelzer, Experiment INRA Versailles-Grignon, France, 2011-2013 
consequences on environmental balances (Nemecek et al. 2008; Jensen et al. 2012). Nevertheless, these services are not very well used today, either because they are not really taken into account in crop management (Evans et al. 2001; Thomsen et al. 2001) or because they do not have any commercial value, which is the case of most of the environmental services (Kinzig et al. 2011). However, the effects of developing legumes are significant at scales higher than the field. At farm level, the improvement in nitrogen and environmental balances associated with the introduction of legumes must be understood at succession and cropping system levels. At industrial and food system level, a widened approach to agroecological transition (Wezel et al. 2009) favours the adoption of more environmentally friendly practices for processing and consuming agricultural production (Francis et al. 2003). Within this framework, legumes can be of environmental benefit to sectors into which they are introduced. These benefits could be assessed, then developed, for example by the creation of environmental quality labels. In the same way, relations between legume production and livestock systems deserve to be further developed at local scales, to make use of plant proteins locally and contribute to improving the sustainability of production systems at territorial scales. At the extreme opposite, intensive soyabean cropping in the Argentinian Pampa has the same negative effects globally as intensive cereal systems in Europe. The effects of reducing soyabean cropping in the Argentinian Pampa deserve to be assessed; a diversification of agricultural production could indeed produce environmental and social benefits at the local scale; and the reduction of Argentine production could improve environmental balances at planetary scale, in particular by reducing the transportation of huge volumes of soyabean oil cakes towards Europe and China. So, a research effort must be made to quantify the agroecological services connected with the insertion of legumes into agricultural and food production systems, on the basis of multi-criteria assessment at the scales of cropping systems, farms, territories, sectors and even of the world, in order to shed light on their importance for the people involved in agricultural production, advice and public authorities.

\subsubsection{Assessments with a view to improving the services provided by legumes}

Beyond the global assessments, three particular types of assessments could help to improve the services provided by legumes.

- Assessment of the potential uses of an extended range of species of legumes must be considered, whereas current research is focused on a very small number of species and agronomic management methods (Bridet-Guillaume et al. 2010). For these minor species, the lack of technical references that can be used by farmers to help them make decisions is hindering their development (Meynard et al. 2013). These deficiencies relate in particular to the management of crops under various soil and climate conditions, to their "preceding" effects and to causes of yield accidents. The range of ecosystem services studied must be widened too, in order to provide a more complete assessment of the benefits of legumes (Zhang et al. 2007).

- Assessment of the conditions for a sustainable insertion of legumes into cropping systems has to be carried out. Legume crops are subjected to severe pressure from diseases, and there are very few resistant varieties today. The increase in the health risk associated with the increase in surfaces and the frequency of return in rotations must be quantified, to define the level and/or methods for sustainable insertion into cropping systems. In addition, these species are sensitive to limiting climatic factors: so, assessments have to be made of the cropping methods which will stimulate robust performance in the cropping systems. Finally, although the properties of legumes regarding the nitrogen cycle may increase the resilience of production systems faced with global change, their contribution to mitigating climate change deserves to be better assessed at global scales.

- Environmental assessments of livestock farms using legumes must also be carried out thoroughly. Although the nutritional quality of the grains of protein-rich plants for animal feed is considered to be satisfactory today, their consumption by animals produces waste that is relatively rich in nitrogen, with negative environmental impacts in livestock farming territories. These defects, related to the high solubility of fresh plant proteins (grain or forage), could be corrected by optimising the digestibility of the feed components, either by genetic improvement or by the development of technological pre-treatments applied to the feed. But these improvements to feed can only be developed on the basis of deeper knowledge of the kinetics of the transit, breakdown and absorption of nutrients in the animal's digestive tract. The need for possible technological processing must be taken into account in the organisation of local circuits of production, storage and valorisation (Petit et al. 2012).

3.4 Optimising the management of legume crops in a global approach to ecological intensification

Within the framework of an evolution of the agricultural context towards a reduction of inputs (plant health, fertilisation), it appears crucial today to use new instruments to optimise the agroecological performances of plants in cropping systems. The ecological intensification of agriculture, making best use of interactions between the biological components of agroecosystems, should improve the efficiency of extracting natural resources and the tolerance of pests; they also play a part in 
maintaining biodiversity and associated services. Legumes occupy a particular place in these interactions (a) because of the symbiosis they establish with bacteria in the soil for fixing atmospheric nitrogen and (b) because they contribute to the diversification of European agriculture.

\subsubsection{Intercropping with several plant species}

Intercropping, in space or time, of harvested plants, and/or service plants, is an essential agronomic innovation, which makes best use of natural resources, at crop or rotation level (e.g. Corre-Hellou et al. 2006; Hauggaard-Nielsen et al. 2009). Because of the biological fixation of atmospheric nitrogen, intercropping based on legumes overall makes the most efficient use of nitrogen (Hauggaard-Nielsen et al. 2003), at the same time maintaining a high level of productivity for lower levels of nitrogen fertiliser inputs (compared to fertilised pure crops) (Jensen 1996; Ghaley et al. 2005; Pelzer et al. 2012). Intercropping is also a tool to improve disease and weed management and to reduce pests (Trenbath 1993). Finally, they can provide solutions to improve the quality of the products. Intercropping of legume and non-legume species in the same population is widely used in manual farming systems in the countries of the south (Malézieux et al. 2009). In Western countries, this agronomic practice was originally used in grasslands for fodder production, but it had almost disappeared from cereal-based cropping systems because of the intensification of agriculture. However, intercropping today arouses renewed interest for field crops, in particular in organic farming. In this system, intercropping legumes make it possible to produce cereals with a high protein content, without any nitrogen fertilisation, and the intercropped cereals make legume growing possible (not very competitive against weeds) without using herbicides (Corre-Hellou et al. 2011). A spectacular increase in intercropping has recently been seen in the temporary grassland of mixed crop-livestock systems (more than $70 \%$ of the grasslands sown in 2011-2012). This development allows livestock farmers to reduce purchases of oil cakes and manure whose prices are both high and very variable. Intercropping with well-managed legumes provides positive impacts on the environment, both on the reduction in nitrogen losses (towards water or air) and on the biodiversity of the site.

- For grain production, the development of legume-cereal intercropping is hindered today by control of the mixture composition, adaptation of the sectors and the time necessary for training and disseminating the innovation. Ways of improving the situation first of all involve the rules for assembling and managing the species. For example, the balance between the two species during the cycle depends on various factors, including the proportion of each species in the mixture at sowing and the dynamics of the availability of nitrogen. While the "nitrogen fertilisation" instrument managing the proportion of the species at harvest has been studied (e.g. Naudin et al. 2011), the "proportion of species at sowing" instrument has received less attention (Corre-Hellou et al. 2006). Mention can also be made of the need to create and use appropriate varieties, whereas until now, very little selection work has been carried out with this in mind. Finally, research questions relate to the organisation of the sectors and the economic valorisation of production (and of the ecosystem services produced). Indeed, the practical application of intercropping by farmers remains very limited because of the problems encuntered by collection organisations in terms of logistics (particularly in terms of sorting) and marketing (Bousseau 2009; Magrini et al. 2013). Legume/legume intercropping of varieties or species with complementary characteristics is also probably a promising way of optimising the management of natural resources and/or tolerances to pests; however, this kind of intercropping is not practiced today and there are few references on this subject.

- For forage production, the assets of intercropping perennial grasses and legumes lie in the reduction of nitrogen inputs and in the improvement of the quantity and quality of the fodder produced. The fodder produced allows protein complementation for animals to be reduced; it also offers the possibility of preserving this protein-rich fodder when wet (by baling and wrapping techniques). Indeed, the soluble sugars of grasses improve the valorisation and conservation of proteins. For many decades, adoption by farmers was hindered by the control of the botanical composition of the mixture, as the long-term management over several cycles allowed few possibilities for short-term adjustments. Only the management of defoliation and of mineral nitrogen fertilisation makes it possible to control the respective abundance of grass and legume plants in subsequent cycles. However, many research tasks have provided the keys to understanding and controlling variations in the production of dry matter and quality. The paths to improvement relate today to better knowledge of the rules for assembling species according to the place of production, the exploitation method envisaged (mown or pasture) and the expected lifetime, optimising management rules, and in the long term, genetic progress, through the definition of ideotypes adapted to use in intercropping.

- For the production of services to the crop or the rotation, legumes have a role to play as service plants. Service plants are defined as unharvested co-crops, producing a service to a main crop or rotation. The expected services are a better weed control and a better management of nitrogen fertilisation. Mention can be made, for example, of the use of legumes as cover plants sown in relay in organic wheat (Amossé et al. 2013), or the use of frost- 
tender legumes sown in winter oilseed rape, which could control weeds under oilseed rape in the autumn and restore nitrogen to the rape in the spring, thanks to the mineralisation of the legume (Valantin-Morison et al. 2012). The methods of introducing legumes as service plants have until now been the subject of very few studies. Their adoption has been slowed down by the identification of species and varieties tested for this kind of use, by the cost involved and by the risks associated with the establishment of service crops. The questions to be dealt with concern the identification of suitable assemblies and their spatial and temporal arrangements and the best comprehension and quantification of the services produced. For such an emerging use, the question is whether varieties have to be developed from species already widely used for producing grains or fodder, identifying varieties on the basis of particular features, or if new species should be used whose functional features would seem particularly appropriate for such a use. Among the known fodder species, there is the common tare, an annual species widely used in winter or spring crops, for which there is a significant plant breeding programme. Among the new species, there is common bird's foot or serradella (Ornithopus sativus) or fenugreek (Trigonella foeniculumgraecum). But in this case, varietal availability is limited, as is the resource in seeds of known germinative quality.

\subsubsection{Interactions between plants and microorganisms of the rhizosphere}

The rhizosphere is a special area for interactions between the plant's root system, the soil and the organisms living there
(Fig. 14) (Hinsinger et al. 2005; Lambers et al. 2009). The driving force of these interactions is the release by the plant of organic compounds according to the rhizodeposition process (Nguyen 2003). These compounds intervene not only as "signal" molecules, but also as nutrients for the soil microorganisms (mainly heterotrophic) (Bais et al. 2006). These interactions are classically represented according to a gradient going from symbiotic mutualism to parasitism, and they can be analysed in terms of costs and benefits for each partner. For the plant, the high metabolic cost of rhizodeposition is compensated by benefits in terms of growth (supply of mineral elements, better hydrous supply) and of protection against parasites. In return, the metabolic cost for the microorganisms to express these functions is compensated by the benefit in using the rhizodeposits produced by the plant (Lambers et al. 2009). The plant-microorganism interactions can be an important instrument for improving the agroecological performances of plants in general and legumes in particular, but this fact has never really been quantified.

Legumes have the peculiarity of establishing symbiotic relations with bacteria of the Rhizobia genus and with endomycorrhizian fungi. These symbioses are not only limited intrinsically by a cost in energy at the level of the plant, but also by the biotic or abiotic environment. Thus, fixing symbiosis is very sensitive to water stress, to phosphorus limitation and to a fungal disease of the root system (Aphanomycès Euteiches). Research dedicated to the analysis of plant-microorganism interactions in the rhizosphere was restricted, until recently, to the study of the molecular and physiological bases of the interaction of mutually beneficial microorganisms of the symbiotic type (nitrogen-fixing bacteria and mycorrhizae), and the immense range of interactions between the plant and microbial communities was not taken into account (Mougel
Fig. 14 Schematic scheme of the interactions between plant and sol micobes

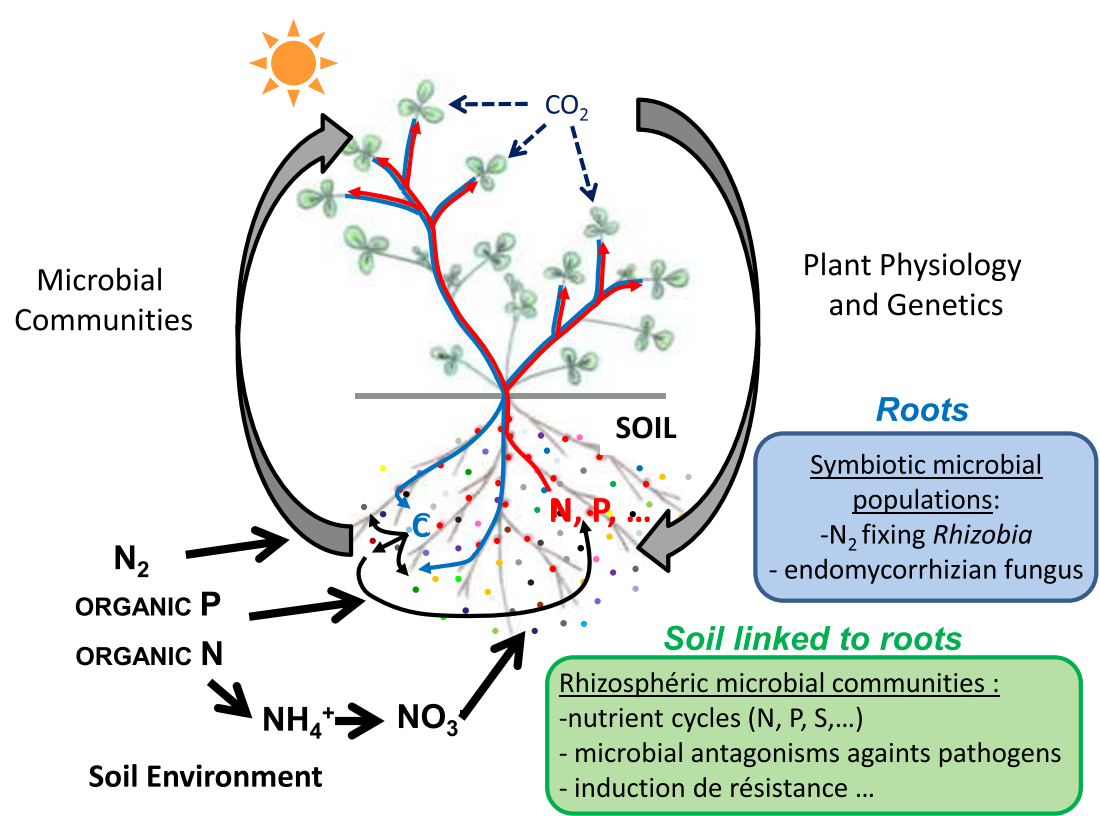


et al. 2006; Zancarini et al. 2013a). However, all of the microbial communities of the soil can contribute to improving the growth and health of plants; more specifically, they can improve the establishment and effectiveness of symbioses, by the provision of water and mineral elements necessary to their functioning and/or by protection against biotic stresses. However, the capacities of cultivated plants to maintain these interactions were not taken into account-even counter-selected - in past selection programmes, carried out in high-input systems. This offers prospects of restoring them by genetic improvement. The establishment of these interactions represents a cost for the plant, and their expression is restricted to limiting environmental conditions (e.g. the inhibition of nitrogen fixing symbiosis in the presence of nitrate and of endomycorrhizian symbiosis in the presence of phosphate). These interactions must therefore be better identified, and quantified, in relation to the services provided, by assessing the respective roles of the genetic diversity of microorganisms in the rhizosphere, the genetic diversity of the plants, the farming practices and the environmental conditions (Zancarini et al. 2013b). For physiologists, it is a question of identifying the properties of the plant which are involved in the assembly of microbial communities and, symmetrically, for microbiologists to identify the microbial properties which have an effect on the plant. In genetics, the question is to identify the genes of the plant which control the selection of interactions with microorganisms in the soil (Friesen et al. 2011). The possibilities of piloting these interactions via the plant genotype must be assessed and the expected benefit quantified by multi-criteria assessments.

\section{Conclusion: what transitions are there for researchers?}

\subsection{A new positioning of research questions}

For researchers, this reflection leads to repositioning questions about legumes in terms of agroecology in the wider sense, for a transition towards more diversified and more sustainable production systems, which will therefore be more flexible and more resilient. The broader definition of agroecology as "The integrative study of the ecology of the entire food system, encompassing ecological, economic and social dimensions" (Francis et al. 2003) invites us to put questions at the level of the entire food system, and not just at the levels of the field or the farm, as an agronomist would do, or of processing products, as a technologist would. This new positioning leads to opening up new horizons of research and a new ranking of priorities. By changing the point of view, we can envisage working our way around situations which used to appear inextricable. For example, it appears difficult to bring together the conditions required for developing the use of pea in animal feed, but if the challenge is changed, putting forward the question of food safety, attention is focused on the interest in developing research into technological innovation and the construction of food sectors. The fact that this research has not been developed very much in the past allows us to predict an important margin of progress.

Agroecology puts forward the principle that increased diversity of production systems increases their sustainability (Altieri 1992; Ratnadass et al. 2012): a transition of research must take place from model species and/or dominant species towards a diversification of the species studied, developing in genetics the conservation of synteny between close species, and mobilising concepts of compared ecophysiology and functional ecology for the required biological functions. An important departure consists of envisaging genetic and agronomic innovations, not as the major instrument for adapting to one majority outlet (animal feed), but from a new angle relating to (1) a collection of new outlets by analysing market potential according to the specific, functional and nutritional properties of legumes, (2) technological solutions suggested by actors in R\&D which can mitigate "defects of quality" and (3) the particular properties of legumes for their importance in ecologically intensive production systems according to various methods of insertion into cropping systems.

\subsection{Collective implementation and learning about transition}

The questions put forward in the previous paragraphs often concern multi-disciplinary and multi-scale research. They call for the building of integrated projects, favouring the coconstruction of problems by the various disciplines. One difficulty lies in the mobilisation of the skills of certain disciplines until now not very much involved in legumes, such as economic and social sciences, sciences of food and nutrition, process engineering, agronomy and ecology (Bridet-Guillame et al. 2010). Finally, researchers and stakeholders in the sectors have to be brought closer together, to better understand the technology and organisational innovations necessary for the transition of the entire agricultural and agro-industrial production system towards more sustainability.

Research and teaching have a key role to play in collective learning about the transition towards farming systems integrating more legumes, by helping to mobilise the actors with new training (Kemp et al. 1998). Initial and in-service training have a major function in the diffusion of innovations. Indeed, the major part of advice and technical references are brought to farmers by storage organisations; however, their current requirements in terms of supply (in quantity, quality and stability) mean that today they are not very inclined or trained to provide technical support on legume crops.

4.3 What generic value is there in considering the example of France?

This article draws up a general statement of the priorities of research on the example of the French situation. However, its 
variation in a region or a particular area and its adaptation to the evolution of the context are not trivial. The dynamics of knowledge, and the perception by the research team of the "social demand", are part of the equation. Light can be shed on the dynamics of knowledge by a bibliometric analysis such as the one carried out by Bridet-Guillame et al. (2010) because it identifies the strengths and weaknesses of the research. It emerges that at international level, the predominance of research in genetics and physiology would deserve to be questioned, in view of the relatively low investments in agronomy, in the ecology of soils, in sciences of food and human nutrition and in economic and social sciences. In France, a large proportion of work relating to model species with no agronomic interest is an invitation to grant a major place to research into ways of transposing knowledge from one species to another. The perception by researchers of social demand can have various sources: explicit requests by certain stakeholders (economic partners, media, public authorities, etc.) and multi-criteria assessments of current farming and food systems and/or participative forecasts on their evolution, which can result in working on the weaknesses identified or in designing more satisfactory systems. The work of researchers can thus provide information which will help public authorities to arbitrate between possible futures. The general scope of the analysis suggested here is to show that an agroecological vision involves repositioning each brick from work by each specialist, looking at the food system as a whole and integrating issues of eco-design and the life cycle of products. From this viewpoint, each researcher must endeavour to clarify the chain of knowledge which would be likely to link his/her research to innovation and social utility; each researcher must be concerned about the use which can be made of the knowledge he/she is producing; and each researcher must wonder about what his/her skills and field of research enable him/her to produce and that would be useful to other researchers. This is what we have tried to do in this article.

Acknowledgments This papers brings about the main conclusions of the wokshop that was held in Dijon, France, on 27-28 September 2011 and entitled "Atelier de réflexion pour un renouvellement des questions de recherche sur les légumineuses: du gène à la filière" (in English: "brainstorming workshop on the renewal of research questions on legumes: from gene to supply chain"). The authors therefore thank all the participants for the fruitful discussion during this workshop. Our grateful thanks are also due to Jane Curtis-Williams for editing the English.

\section{References}

Allaire G (2012) The multidimensional definition of quality. In: SaavedraRivano N, Ilbert H, Augustin-Jean L (eds) Geographical indications and international agricultural trade. Macmillan, New York, pp 71-90

Altieri MA, Martin PB, Lewis WJ (1983) A quest for ecologically based pest management systems. JEnviron Manag 7:91-100. doi:10.1007/ bf01867047
Altieri MA (1992) Agroecological foundations of alternative agriculture in California. Agric Ecosyst Environ 39:23-53. doi:10.1016/01678809(92)90203-n

Altieri MA, Nicholls CI (2012) Agroecology scaling up for food sovereignty and resiliency. Sustain Agric Rev 11:1-29. doi:10. 1007/978-94-007-5449-2 1

Amossé C, Jeuffroy MH, David C (2013) Relay intercropping of legume cover crops in organic winter wheat: effects on performance and resource availability. Field Crop Res 145:78-87. doi:10.1016/j.fcr. 2013.02.010

Anderson JW, Major AW (2002) Pulses and lipaemia, short- and longterm effect: potential in the prevention of cardiovascular disease. $\mathrm{Br}$ J Nutr 88:263-271. doi:10.1079/bjn.2002716

Arthur WB (ed) (1994) Increasing returns and path dependence in the economy. University Michigan press.

Aubertot JN, Barbier JM, Carpentier A, Gril JJ, Guichard L, Luca S, Savary S, Savini S, Voltz M (2005) Pesticides, agriculture et environnement. Réduire l'utilisation des pesticides et limiter leurs impacts environnementaux. http://www6.paris.inra.fr/depe/Projets/ Pesticides-agriculture-et-environnement. Accessed 18 Oct 2013

Axelos M, Bérot S, Schmidt I, Guéguen J (2006) Propriétés tensioactives de biopolymères amphiphiles. In: Colonna P (ed) La Chimie verte. Lavoisier, Paris, pp 271-304

Bais HP, Weir TL, Perry LG, Gilroy S, Vivanco JM (2006) The role of root exudates in rhizosphere interactions with plants and other organisms. Annu Rev Plant Biol 57:233-266. doi:10.1146/ annurev.arplant.57.032905.105159

Berthet ETA, Bretagnolle V, Segrestin B (2012) Analyzing the design process of farming practices ensuring little bustard conservation: lessons for collective landscape management. J Sustain Agric 36: 319-336. doi:10.1080/10440046.2011.627988

Boland MJ, Rae AN, Vereijken JM, Meuwissen MPM, Fischer ARH, van Boekel MAJS, Rutherfurd SH, Gruppen H, Moughan PJ, Hendriks WH (2013) The future supply of animal-derived protein for human consumption. Trends Food SciTechnol 29:62-73. doi:10.1016/j.tifs. 2012.07.002

Bousseau D (2009) Mixtures of cereals and protein crops and mixtures of bread wheat varieties: agronomic point of view and practices of a coop. Innov Agronomiques 7:129-137

Bridet-Guillaume F, Millot D, Buitink J, Gueguen J, Jeuffroy MH, Le Gall M, Munier-Jolain NG, Duc G (2010) Bibliometric analysis of French and worldwide scientific literature on grain legume crops from 2000 to 2009: comparison to soyabean and model species. Innov Agronomiques 11:137-145

Butault JP, Dedryver CA, Gary C, Guichard L, Jacquet F, Meynard JM, Nicot P, Pitrat M, Reau R, Sauphanor B, Savini I, Volay T (2010) Ecophyto R\&D, Quelles voies pour réduire l'usage des pesticides? INRA-Cemagref Multidisciplinary Scientific Assessment, France. http://www6.paris.inra.fr/depe/Projets/Ecophyto-R-D. Accessed 18 Oct 2013

Carrouée B, Schneider A, Flénet F, Jeuffroy MH, Nemecek T (2012) Introduction of dry pea crop in rotations of cereals and rapeseed: impact on the economic and environmental performances. Innov Agronomiques 25:125-142

Cavaillès E (2009) La relance des légumineuses dans le cadre d'un plan protéines: quels bénéfices environnementaux? Etudes et Documents, $n^{\circ} 15$, Commissariat Général au Développement Rural, France. http://www.developpement-durable.gouv.fr/spip. php?page $=$ article\&id_article $=12730$. Accessed 18 Oct 2013

Chatellier V, Gaigné $\mathrm{C}^{-}$(2012) Les logiques économiques de la spécialisation productive du territoire agricole français. Innov Agronomiques 22:185-203

Colonna P, Mercier C (1985) Pisum sativum and Vicia faba carbohydrates. 6. Gelatinization and melting of maize and pea starches with normal and high amylase genotypes. Phytochemistry 24:1667-1674. doi:10.1016/S0031-9422(00)82532-7 
Corre-Hellou G, Crozat $\mathrm{Y}$ (2005) $\mathrm{N}_{2}$ fixation and $\mathrm{N}$ supply in organic pea (Pisum sativum L.) cropping systems as affected by weeds and peaweevil (Sitona lineatus L.). Eur J Agron 22(4):449-458. doi: 10.1016/j.eja.2004.05.005

Corre-Hellou G, Fustec J, Crozat Y (2006) Interspecific competition for soil $\mathrm{N}$ and its interaction with $\mathrm{N}_{2}$ fixation, leaf expansion and crop growth in pea-barley intercrops. Plant Soil 282:195-208. doi:10. 1007/s11104-005-5777-4

Corre-Hellou G, Dibet A, Hauggaard-Nielsen H, Crozat Y, Gooding M, Ambus P, Dahlmann C, von Fragstein P, Pristeri A, Monti M, Jensen ES (2011) The competitive ability of pea-barley intercrops against weeds and interactions with crop productivity and soil $\mathrm{N}$ acquisition. Field Crop Res 122:264-272. doi:10.1016/j.fcr.2011.04.004

Cowan R, Gunby P (1996) Sprayed to death: path dependence, lock-in and pest control strategies. Econ J 106:521-542

David C, Jeuffroy MH, Henning J, Meynard JM (2005) Yield variation in organic winter wheat: a diagnostic study in the Southeast of France. Agron Sustain Dev 25:213-223. doi:10.1051/agro:2005016

Dorin B, Treyer S, Paillard S (2011) Agrimonde-scenarios and challenges for feeding the world in 2050. Editions Quae, Paris. http://www.foresight-platform.eu/brief/efp-brief-no-196agrimonde/. Accessed 18 Oct 2013

Esnouf C, Russel M, Bricas N (2011) Pour une alimentation durable. Réflexion stratégique duALIne. Editions Quae, Paris. http://www. cirad.fr/publications-ressources/edition/etudes-et-documents/dualine

Evans J, McNeill AM, Unkovich MJ, Fettell NA, Heenan DP (2001) Net nitrogen balances for cool-season grain legume crops and contributions to wheat nitrogen uptake: a review. Aust J Exp Agric 41:347-359. doi:10.1071/ea00036

FAO (2009) The state of food and agriculture. Livestock in the balance. http://www.fao.org/docrep/012/i0680e/i0680e.pdf. Accessed 18 Oct 2013

Fares M, Magrini MB, Triboulet P (2012) Agroecological transition, innovation and lock-in effects: the impact of the organizational design of supply chains. Cah Agric 21:34-45. doi:10.1684/agr. 2012.0539

Francis C, Lieblein G, Gliessman S, Breland TA, Creamer N, Harwood R, Salomonsson L, Helenius J, Rickerl D, Salvador R, Wiedenhoeft M, Simmons S, Allen P, Altieri M, Flora C, Poincelot R (2003) Agroecology: the ecology of food systems. J Sustain Agr 22:99118. doi:10.1300/J064v22n02_07

Friesen ML, Porte SS, Stark SC, von Wettber EJ, Sachc JL, MartinezRomero E (2011) Microbially mediated plant functional traits. Ann Rev Ecol Evol Syst 42:23-46. doi:10.1146/annurev-ecolsys102710-145039

Geels FW (2011) The multi-level perspective on sustainability transitions: response to seven criticisms. Environn Innov Soc Transit 1:24-40

Géhin B, Guéguen J, Bassot P, Seger A (2010) To specific quality requirements to increase use of legumes for industrial processing. Innov Agronomiques 11:115-127

Ghaley BB, Hauggaard-Nielsen H, Hogh-Jensen H, Jensen ES (2005) Intercropping of wheat and pea as influenced by nitrogen fertilization. Nutr Cycl Agroecosys 73:201-212. doi:10.1007/ s10705-005-2475-9

Guéguen J (1983) Legume seed protein extraction, processing and end product characteristics. Qualitas Plantarum Plant foods for Human Nutrition 33:267-303

Guéguen J (1999) Les protéines végétales: un réservoir de macromolécules multifonctionnelles. OCL 6:498-504. doi:10. 1007/BF01091191

Guilbert S, Morel MH, Cuq B (2006) Protéines matériaux. In: Colonna P (ed) La Chimie verte. Lavoisier, Paris, pp 179-204

Hauggaard-Nielsen H, Ambus P, Jensen ES (2003) The comparison of nitrogen use and leaching in sole cropped versus intercropped pea and barley. Nutr Cycl Agroecosys 65:289-300
Hauggaard-Nielsen H, Gooding M, Ambus P, Corre-Hellou G, Crozat Y, Dahlmann C, Dibet A, von Fragstein P, Pristeri A, Monti M, Jensen ES (2009) Pea-barley intercropping for efficient symbiotic $\mathrm{N}_{2^{-}}$ fixation, soil $\mathrm{N}$ acquisition and use of other nutrients in European organic cropping systems. Field Crops Res 113:64-67. doi:10.1016/ j.fcr.2009.04.009

Heng L, Vincken JP, Koningsveld V, Legger A, Gruppen H, Van Boekel T, Roozen J, Voragen F (2006a) Bitterness of saponins and their content in dry peas. J Sci Food Agric 26(8):1225-1231. doi:10. $1002 /$ jsfa. 2473

Heng L, Vincken JP, Hoppe K, Koningsveld V, Decroos K, Gruppen H, Van Boekel MAJS, Voragen AGJ (2006b) Stability of pea DDMP saponin and the mechanism of its decomposition. Food Chem 99(2): 326-334. doi:10.1016/j.foodchem.2005.07.045

Hill SB, MacRae RJ (1995) Conceptual framework for the transition from conventional to sustainable agriculture. J Sustain Agr 7:81-87

Hinsinger P, Gobran GR, Gregory PJ, Wenzel WW (2005) Rhizosphere geometry and heterogeneity arising from root-mediated physical and chemical processes. New Phytol 168:293-303. doi:10.1111/j.14698137.2005.01512.x

Jensen ES (1996) Grain yield, symbiotic $\mathrm{N}_{2}$ fixation and interspecific competition for inorganic N in pea-barley intercrops. Plant Soil 182: 25-38. doi:10.1007/bf00010992

Jensen E, Peoples M, Boddey R, Gresshoff P, Hauggaard-Nielsen H, Alves BJR, Morrison M (2012) Legumes for mitigation of climate change and the provision of feedstock for biofuels and biorefineries. A review. Sustain Dev 32:329-364. doi:10.1007/s13593-011-0056-7

Jensen ES, Hauggaard-Nielsen H (2003) How can increased use of biological $\mathrm{N}_{2}$ fixation in agriculture benefit the environment? Plant Soil 252:177-186. doi:10.1023/a:1024189029226

Jeuffroy MH, Baranger E, Carrouée B, de Chezelles E, Gosme M, Hénault C, Schneider A, Cellier P (2013) Nitrous oxide emissions from crop rotations including wheat, rapeseed and dry peas. Biogeosciences 10:1787-1797

Kemp R, Schot J, Hoogma R (1998) Regime shifts to sustainability through processes of niche formation: the approach of strategic niche management. Tech Anal Strat Manag 10:175-195. doi:10. 1080/09537329808524310

Kinzig AP, Perrings C, Chapin FS, Polasky S, Smith VK, Tilman D, Turner BL (2011) Paying for ecosystem services-promise and peril. Science 334:603-604. doi:10.1126/science.1210297

Labarthe P (2010) Services immatériels et verrouillage technologique. Le cas du conseil technique aux agriculteurs. Econ Soc 44:173-196

Lamb JFS, Jung HJG, Sheaffer CC, Samac DA (2007) Alfalfa leaf protein and stem cell wall polysaccharide yields under hay and biomass management systems. Crop Sci 47:1407-1415. doi:10.2135/ cropsci2006.10.0665

Lambers H, Mougel C, Jaillard B, Hinsinger P (2009) Plant-microbe-soil interactions in the rhizosphere: an evolutionary perspective. Plant Soil 321:83-115. doi:10.1007/s11104-009-0042-x

Lamine C (2005) Settling the shared uncertainties: local partnerships between producers and consumers. Sociol Rural 45(4):324-345. doi:10.1111/j.1467-9523.2005.00308.x

Le Roux X, Barbault R, Baudry J, Burel F, Doussan I, Garnier E, Herzog F, Lavorel S, Lifran R, Roger-Estrade J, Sarthou JP, Trommetter M (2008) Agriculture and biodiversity benefiting from synergies. INRA Multidisciplinary Scientific Assessment. http://www6.paris. inra.fr/depe/Projets/Agricultureet-biodiversite. Accessed 18 Oct 2013

Lessirard J (2009) Amélioration de la qualité nutritionnelle des produits alimentaires. Rapport du Conseil général de l'agriculture, de l'alimentation et des espaces ruraux. CGAAER no 1824, $71 \mathrm{p}$. http://agriculture.gouv.fr/IMG/pdf/Rapport_1824_Amelioration_ Qualite_Nutritionnelle.pdf

Leterme P (2002) Recommendations by health organizations for pulse consumption. Br J Nutr 88:239-242. doi:10.1079/BJN2002712 
Lourdin D, Della Valle G, Colonna P (1995) Influence of amylose content on starch films and foams. Carbohyd Polym 27:261-270. doi:10. 1016/0144-8617(95)00071-2

Lourdin D, Colonna P (2006) Matériaux à base d'amidons et de leurs dérivés. In: Colonna P (ed) La Chimie verte. Lavoisier, France, pp $145-178$

Magrini MB, Triboulet P, Bedoussac L (2013) Pratiques agricoles innovantes et logistique des coopératives agricoles. Une étude exante sur l'acceptabilité de cultures associées blé dur-légumineuses. Economie Rurale 38, in press

Malézieux E, Crozat Y, Dupraz C, Laurans M, Makowski D, OzierLafontaine H, Rapidel B, de Tourdonnet S, Valantin-Morison M (2009) Mixing plant species in intercropping systems: concepts, tools and models. A review. Agron Sustain Dev 29:43-62. doi:10. 1051/agro:2007057

Martin C, Thomsen MH, Hauggaard-Nielsen H, Thomsen AB (2008) Wet oxidation pretreatment, enzymatic hydrolysis and simultaneous saccharification and fermentation of clover-ryegrass mixtures. Bioresource Technol 99:8777-8782. doi:10.1016/j.biortech.2008. 04.039

Meynard JM, Messéan A, Charlier A, Charrier F, Farès M, Le Bail M, Magrini MB, Savini I (2013) Freins et leviers à la diversification des cultures. Etude au niveau des exploitations agricoles et des filières. INRA Multidisciplinary Scientific Assessment. http://www6.paris. inra.fr/depe/Projets/Diversificationdes-cultures. Accessed 18 Oct 2013

Millennium Ecosystem Assessment (2005) Ecosystems and human wellbeing: general synthesis. World Resources Institute. Island Press, Washington DC. www.millenniumassessment.org. Accessed 18 Oct 2013

Mougel C, Offre P, Ranjard L, Corberand T, Gamalero E, Robin C, Lemanceau P (2006) Dynamic of the genetic structure of bacterial and fungal communities at different development stages of Medicago truncatula Jemalong J5. New Phytol 170:165-175

Muchnik J, de Sainte Marie C (2009) Le temps des Systèmes Agroalimentaires Localisés. QUAE editions, Paris

Munier-Jolain NG, Salon C (2005) Are the carbon costs of seed production related to the quantitative and qualitative performance? An appraisal for legumes and other crops. Plant Cell Environ 28: 1388-1395. doi:10.1111/j.1365-3040.2005.01371.x

Naudin C, Corre-Hellou G, Pineau S, Crozat Y, Jeuffroy MH (2011) The effect of various dynamics of $\mathrm{N}$ availability on winter pea-wheat intercrops: crop growth, $\mathrm{N}$ partitioning and symbiotic $\mathrm{N}_{2}$ fixation. Field Crops Res 119:2-11. doi:10.1016/j.fcr.2010.09.007

Nemecek T, Von Richthofen JS, Dubois G, Casta P, Charles R, Pahl H (2008) Environmental impacts of introducing grain legumes into European crop rotations. Eur J Agron 28:380-393

Nguyen C (2003) Rhizodeposition of organic C by plants: mechanism and controls. Agronomie 23:375-396. doi:10.1051/agro:2003011

Pelzer E, Bazot M, Makowski D, Corre-Hellou G, Naudin C, Al Rifaï M, Baranger E, Bedoussac BV, Boucheny P, Carrouée B, Dorvillez D, Foissy D, Gaillard B, Guichard L, Mansard MC, Omon B, Prieur L, Yvergniaux M, Justes E, Jeuffroy MH (2012) Pea-wheat intercrops in low-input conditions combine high economic performances and low environmental impacts. Eur J Agron 40:39-53. doi:10.1016/j. eja.2012.01.010

Petersson A, Thomsen MH, Hauggaard-Nielsen H, Thomsen AB (2007) Potential bioethanol and biogas production using lignocellulosic biomass from winter rye, oilseed rape and faba bean. Biomass and Bioenerg 31:812-819. doi:10.1016/j.biombioe.2007.06.001

Petit MS, Challan-Belval C, Blosseville N, Blancard S, Castel T, Lecomte C, Duc G (2012) The management of crop-livestock systems at a territory level: the example of grain legume crops and of monogastric livestock in Burgundy. France Innov Agronomiques 22:135-157

Ratnadass A, Fernandes P, Avelino J, Habib R (2012) Plant species diversity for sustainable management of crop pests and diseases in agroecosystems: a review. Agron Sustain Dev 32:273-303. doi:10. 1007/s13593-011-0022-4

Rochette P, Janzen HH (2005) Towards a revised coefficient for estimating $\mathrm{N}_{2} \mathrm{O}$ emissions from legumes. Nutr Cycl Agroecosys 73:171-179. doi:10.1007/s10705-005-0357-9

Roep D, Wiskerke JSC (2012) Reshaping the foodscape. In: Spaargaren G, Oosterveer P, Loeber A (eds) Food practices in transition: changing food consumption, retail and production in the age of reflexive modernity. Routledge, New York, pp 207-228

Schott C, Mignolet C, Meynard JM (2010) Les oléoprotéagineux dans les systèmes de culture: évolution des assolements et des successions culturales depuis les années 1970 dans le bassin de la Seine. OCL 17:1-16

Thomsen IK, Kjellerup V, Christensen BT (2001) Leaching and plant offtake of $\mathrm{N}$ in field pea/cereal cropping sequences with incorporation of ${ }^{15} \mathrm{~N}$-labelled pea harvest residues. Soil Use Manag 17:209-216. doi:10.1079/SUM200179

Thomsen MH, Hauggaard-Nielsen H (2008) Sustainable bioethanol production combining biorefinery principles using combined raw materials from wheat undersown with clover-grass. J Ind Microbiol Biotechnol 35:303-311. doi:10.1007/s10295-008-0334-9

Trenbath BR (1993) Intercropping for the management of pests and diseases. Field Crops Res 34:381-405. doi:10.1016/03784290(93)90123-5

Vadez V, Berger JD, Warkentin T, Asseng S, Ratnakumar PC, Rao KP, Gaur PM, Munier-Jolain NG, Larmure A, Voisin AS, Sharma HC, Pande S, Sharma M, Krishnamurthy L, Zaman MA (2012) Adaptation of grain legumes to climatic changes: a review. Agron Sustain Dev 32(1):31-44. doi:10.1007/s13593-011-0020-6

Valantin-Morison M Butier A, Berder J, Pinochet X (2012) Crop growth and nitrogen utilisation of a mixture of winter oilseed rape (Brassica napus-WOSR) and legume in multi-local trials. Proceedings of the XIIth congress of the European Society of Agronomy, Helsinki, 1924 August 2012

Vanloqueren G, Baret PV (2009) How agricultural research systems shape a technological regime that develops genetic engineering but locks out agroecological innovations. Res Policy 38:971-983

Vose JR (1980) Production and functionality of starches and protein isolates from legume seeds (field peas and horsebeans). Cereal Chem 57:406-410

Wezel A, Bellon S, Doré T, Francis C, Vallod D, David C (2009) Agroecology as a science, a movement and a practice. A review. Agron Sustain Dev 29:503-515. doi:10.1051/agro/2009004

Zancarini A, Mougel C, Terrat S, Salon C, Munier-Jolain NG (2013a) Combining ecophysiological and microbial ecological approaches to study the relationship between Medicago truncatula genotypes and their associated rhizosphere bacterial communities. Plant Soil 365:183-199

Zancarini A, Lépinay C, Burstin J, Duc G, Lemanceau P, Moreau D, Munier-Jolain NG, Pivato B, Rigaud T, Salon C, Mougel C (2013b) Combining molecular microbial ecology with ecophysiology and plant genetics for a better understanding of plant-microbial communities interactions in the rhizosphere. In: Bruijn FJ (ed) Molecular microbial ecology of the rhizosphere. Wiley, New York, in press

Zhang W, Ricketts TH, Kremenc C, Carneyd K, Swintona SM (2007) Ecosystem services and dis-services to agriculture. Ecol Econ 64: 253-260. doi:10.1016/j.ecolecon.2007.02.024 